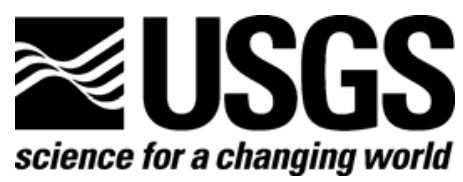

In Cooperation with the Southern Nevada Water Authority

\title{
Audiomagnetotelluric Data and Two- Dimensional Models from Spring, Snake, and Three Lakes Valleys, Nevada
}

By Darcy K. McPhee, Bruce A. Chuchel, and Louise Pellerin

Report Series 2007-1181

U.S. Department of the Interior

U.S. Geological Survey 


\title{
U.S. Department of the Interior DIRK KEMPTHORNE, Secretary
}

\author{
U.S. Geological Survey \\ Mark D. Myers, Director
}

U.S. Geological Survey, Reston, Virginia 2007

For product and ordering information:

World Wide Web: http://www.usgs.gov/pubprod

Telephone: 1-888-ASK-USGS

For more information on the USGS - the Federal source for science about the Earth, its natural and living resources, natural hazards, and the environment:

World Wide Web: http://www.usgs.gov

Telephone: 1-888-ASK-USGS

Suggested citation:

McPhee, Darcy K., Chuchel, Bruce A., and Pellerin, Louise, 2007, Audiomagnetotelluric data and two-dimensional models from Spring, Snake, and Three Lakes Valleys, Nevada: U.S. Geological Survey Open-File Report 2007-1181, 47 p.

[http://pubs.usgs.gov/of/2007/1181/].

Any use of trade, product, or firm names is for descriptive purposes only and does not imply endorsement by the U.S. Government.

Although this report is in the public domain, permission must be secured from the individual copyright owners to reproduce any copyrighted material contained within this report. 


\section{Contents}

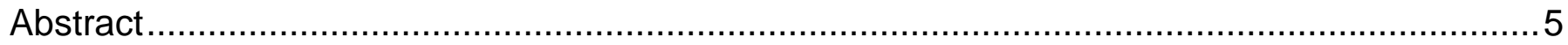

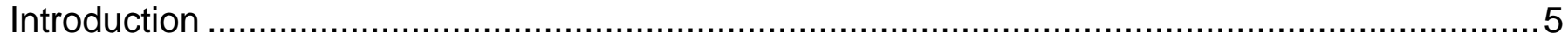

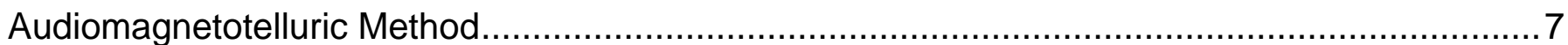

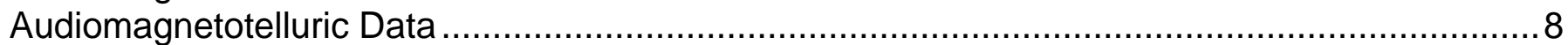

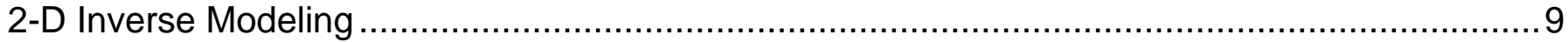

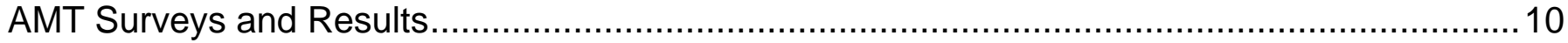

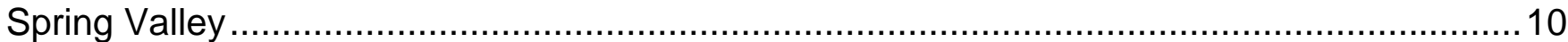

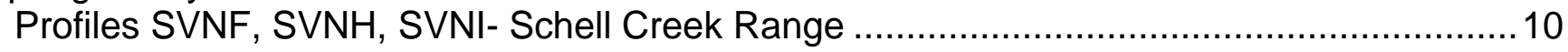

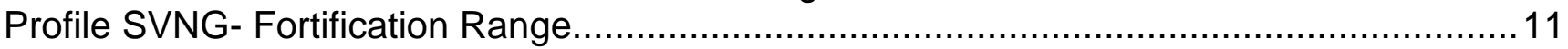

Profiles SVNM, SVNK, SVNL, SVNJ- Southern Snake Range ...................................... 11

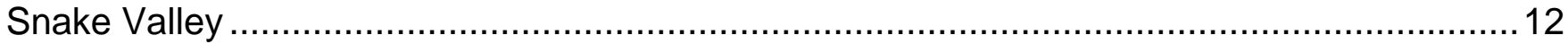

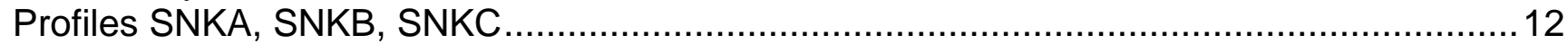

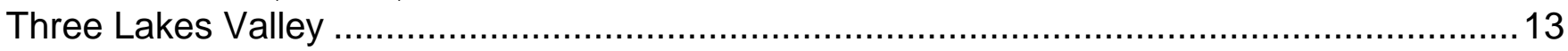

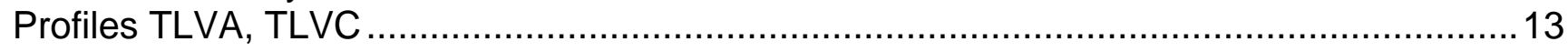

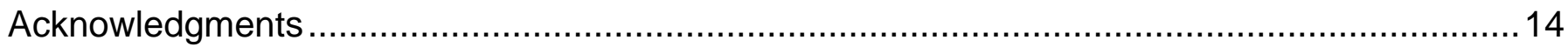

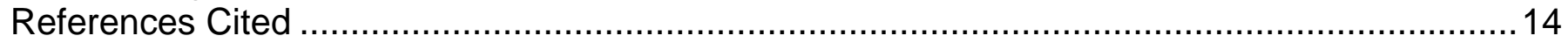

\section{Figures}

Figure 1. Topographic map of study area showing location of AMT profiles in Spring and Snake Valleys. Profiles A and B were collected in 2004 and are presented in McPhee and others (2006).

Figure 2. Topographic map of study area showing location of AMT profiles in southern Three Lakes Valley.

Figure 3. 2-D inverse model computed from the TM mode data along profile SVNF in Spring Valley.

Figure 4. Pseudosections of observed data and model response for the apparent resistivity and phase along profile SVNF. Black dots show data points. ........................20

Figure 5. 2-D inverse model computed from the TM mode data along profile SVNH in Spring Valley.

Figure 6. Pseudosections of observed data and model response for the apparent resistivity and phase along profile SVNH. Black dots show data points.

Figure 7. 2-D inverse model computed from the TM mode data along profile SVNI in Spring Valley.

Figure 8. Pseudosections of observed data and model response for the apparent resistivity and phase along profile SVNI. Black dots show data points...........................24 Figure 9. 2-D inverse model computed from the TM mode data along profile SVNG in Spring Valley.

Figure 10. Pseudosections of observed data and model response for the apparent resistivity and phase along profile SVNG. Black dots show data points.....

Figure 11. 2-D inverse model computed from the TM mode data along profile SVNM in Spring Valley. 
Figure 12. Pseudosections of observed data and model response for the apparent resistivity and phase along profile SVNM. Black dots show data points..........................28

Figure 13. 2-D inverse model computed from the TM mode data along profile SVNK in Spring Valley.

Figure 14. Pseudosections of observed data and model response for the apparent resistivity and phase along profile SVNK. Black dots show data points. .........................30

Figure 15. 2-D inverse model computed from the TM mode data along profile SVNL in Spring Valley.

Figure 16. Pseudosections of observed data and model response for the apparent resistivity and phase along profile SVNL. Black dots show data points...........................32

Figure 17. Pseudosections of observed data only for the TE and TM mode apparent resistivity and phase along profile SVNJ.

Figure 18. 2-D inverse model computed from the TM mode data along profile SNKA in Snake Valley. Note that resistivity scale is different from that used in Spring Valley models.

Figure 19. Pseudosections of observed data and model response for the apparent resistivity and phase along profile SNKA. Black dots show data points. ...........................35 Figure 20. 2-D inverse model computed from the TM mode data along profile SNKB in Snake Valley. 36

Figure 21. Pseudosections of observed data and model response for the apparent resistivity and phase along profile SNKB. Black dots show data points.

Figure 22. 2-D inverse model computed from the TM mode data along profile SNKC in Snake Valley. 38

Figure 23. Pseudosections of observed data and model response for the apparent resistivity and phase along profile SNKC. Black dots show data points.

Figure 24. 2-D inverse model computed from the TE+TM mode data along profile TLVA in Three Lakes Valley. Note that resistivity scale is different from that used in Spring and Snake Valley models. 40

Figure 25. Pseudosections of observed data and model response for the apparent resistivity and phase along profile TLVA for both the TE (a) and TM (b) modes. Black dots

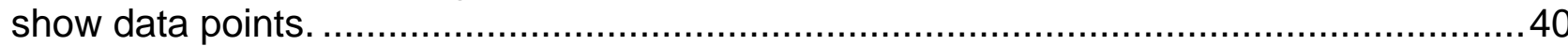
Figure 26. 2-D inverse model computed from the TE+TM mode data along profile TLVC in Three Lakes Valley. 41

Figure 27. Pseudosections of observed data and model response for the apparent resistivity and phase along profile TLVC for both the TE (a) and TM (b) modes. Black dots show data points.

\section{Tables}

Table 1. Description of AMT profiles. 42

Table 2. Sounding numbers, locations, elevations and azimuths of stations along AMT profiles.

\section{Appendix}

A. Sounding curves. 


\title{
Audiomagnetotelluric data and two- dimensional models from Spring, Snake, and Three Lakes Valleys, Nevada
}

\author{
By Darcy K. McPhee ${ }^{1}$, Bruce A. Chuchel ${ }^{1}$, and Louise Pellerin ${ }^{2}$
}

\begin{abstract}
Audiomagnetotelluric (AMT) data along thirteen profiles in Spring, Snake, and Three Lakes Valleys, and the corresponding two-dimensional (2-D) inverse models, are presented. The AMT method is a valuable tool for estimating the electrical resistivity of the Earth over depth ranges of a few meters to roughly one kilometer. It is important for revealing subsurface structure and stratigraphy within the Basin and Range province of eastern Nevada that can be used to define the geohydrologic framework of the region. We collected AMT data using the Geometrics StrataGem EH4 system. Profiles were 1.2 to $4.6 \mathrm{~km}$ in length with station spacing of 100-400 m. Data were recorded in a coordinate system parallel to and perpendicular to the assumed regional geologic strike direction. We show station locations, sounding curves of apparent resistivity, phase, and coherency, and 2-D models. The 2-D inverse models are computed from the transverse electric (TE), transverse magnetic (TM), and TE+TM mode data using the conjugate gradient, finitedifference method of Rodi and Mackie (2001). Preliminary interpretation of these models defines the structural framework of the basins and the resistivity contrasts between alluvial basin-fill, volcanic units, and carbonate/clastic rocks.
\end{abstract}

\section{Introduction}

The Basin and Range province is an arid, mountainous, sparsely populated region of the western United States. Ground-water is organized into extensive regional systems (Harrill and Prudic, 1998) where it can flow between adjacent topographic ranges and basins. The location of basin-fill aquifers, including carbonate rocks, and their hydraulic connectivity to the carbonate-rock aquifer system that underlies the entire eastern two-thirds of the Great Basin (Plume, 1996; Harrill and Prudic, 1998) is important for assessing ground-water resources in the region. Range-front

\footnotetext{
${ }^{1}$ U.S. Geological Survey, 345 Middlefield Rd., MS 989, Menlo Park, CA 94025

${ }^{2}$ Green Engineering, Inc., 2215 Curtis St., Berkeley, CA 94702
} 
faults are a primary structural control on the hydrogeology of the valleys in eastern Nevada, however, structure within the basins is often obscured by basin-fill sediments, hence geophysical investigations are needed to characterize the subsurface structures and stratigraphy influencing ground-water resources. The gravity method has been used to estimate the structure and depth of the basins in eastern Nevada (Mankinen and others, 2007; Mankinen and others, 2006; Scheirer, 2005), but because densities of volcanic rocks in the area may be comparable to the average density of basin sediment-fill, comprised of semi-consolidated to unconsolidated sand, gravel, silt, clay, and local evaporites, it may be difficult to resolve the subsurface geometry of the basin-fill and volcanic rocks using the gravity method alone.

Previous results from eastern Nevada (McPhee and others, 2006), including studies in Spring Valley, show that two-dimensional (2-D) inversion of audiomagnetotelluric (AMT) sounding data defines significant structure within the upper kilometer of the subsurface in a typical basin setting. Detailed structure was observed within alluvial basins such as clear transitions between unsaturated and saturated alluvium/volcanic rocks, high-resistivity (>1000 ohm-m) carbonate rocks, and the locations of range-front and intra-basin faults. In some cases AMT models defined the shape of and depth to the basement, which correlated well with depth to basement estimates derived from inversion of gravity data (Mankinen and others, 2006).

In this study, the AMT method is used in Spring, Snake, and Three Lakes valleys (Figures 1 and 2) to define potential geologic/tectonic structures significant to ground-water exploration. Two separate field surveys were conducted in Spring Valley during Spring/Summer of 2006 using methods identical to those described in McPhee and others (2006). A survey in Snake Valley was conducted in the Fall of 2006, followed by another survey in Three Lakes Valley in April 2007. We were able to delineate range-front faults, structure, and stratigraphy within the basins as well as the overall framework of the basins. These models are being used to help site ground-water exploration wells and are contributing to the geologic framework for hydrologic modeling in the region.

The purpose of this report is to release the AMT sounding data and 2-D inverse models. Hydrogeologic interpretation of the models is not the focus of this report. 


\section{Audiomagnetotelluric Method}

The magnetotelluric (MT) method is a geophysical technique that uses the Earth's natural electromagnetic (EM) fields as a source to investigate the electrical resistivity structure of the subsurface (Telford and others, 1991; Vozoff, 1991). Within the upper crust, the resistivity of geologic units is largely dependent upon their fluid content, porosity, degree of fracturing, temperature, and conductive mineral content (Keller, 1989). Saline fluids within pore spaces and fracture openings can reduce bulk resistivities by several orders of magnitude relative to the dry rock matrix. Resistivity can also be lowered by the presence of conductive clay minerals, graphite, and metallic sulfide mineralization. Up to temperatures of $\sim 300^{\circ} \mathrm{C}$, increased temperatures cause higher ionic mobility and mineral activation energy, reducing rock resistivities significantly (Nesbitt, 1993). Unaltered, unfractured igneous rocks are normally very resistive, with values typically 1,000 ohm-m or greater. Fault zones can appear as low resistivity units of less than 100 ohm-m when they are comprised of rocks fractured enough to host fluid transport and consequent mineralogical alteration (Eberhart-Phillips and others, 1995). Carbonate/clastic rocks are moderately to highly resistive, with values of hundreds to thousands of ohm-m depending upon their fluid content, porosity, fracturing, and impurities. Marine shale, mudstone, and clay-rich alluvium are normally very conductive with values of a few to tens of ohm-m. Unaltered, metamorphic, non-graphitic rocks are moderately to highly resistive. Tables of electrical resistivity for a variety of rocks, minerals and geological environments may be found in Keller (1987) and Palacky (1987).

Using the same theory, the AMT method is used to estimate the electrical resistivity of the Earth over depth ranges of a few meters to about one kilometer, employing a higher frequency range (Zonge and Hughes, 1991). The electrical impedance is a tensor quantity defined by the ratio of time-varying electric $(\mathrm{E})$ to magnetic $(\mathrm{H})$ field measured at the Earth's surface. The surface impedance is a complex function of frequency; higher-frequency data are used for investigation of the near surface and lower-frequency data for greater depths. For a 2-D Earth, the diagonal terms of the impedance tensor are zero, and the off-diagonal terms can be decoupled into transverse electric (TE) and transverse magnetic (TM) modes. When the geology satisfies the 2-D assumption, the data for the TE mode measures electric field parallel to geologic strike, and that for the TM mode measures electric field perpendicular to geologic strike. This 2-D assumption permits significant simplification in the modeling and inversion of MT and AMT data. An AMT sounding 
provides an estimate of resistivity beneath the receiver site and also indicates the geoelectric complexity at the sounding site. In areas where the resistivity distribution does not change rapidly from station to station, the resistivity sounding provides a reasonable estimate of the resistivity layering beneath the site.

The Geometrics StrataGem EH-4 system utilizes both natural and controlled-source electromagnetic signals to obtain a continuous electrical sounding of the Earth beneath the measurement site (Geometrics, 2000). Data are recorded from 92,000 to $10 \mathrm{~Hz}$. The natural field strength is weak around $1,000 \mathrm{~Hz}$ so the controlled source is used to augment the natural field. Surface impedance results are immediately displayed as a resistivity sounding. Data are subsequently modeled using a 2-D inversion algorithm (see 2-D Inverse Modeling section). A more thorough discussion of the Stratagem EH-4 system used in this study is contained in Geometrics (2000) and McPhee and others (2006).

\section{Audiomagnetotelluric Data}

After transforming the recorded time-series data to the frequency domain, EM transfer functions are estimated (Geometrics, 2000) from which the apparent resistivity and phase tensor can be calculated at each site. Apparent resistivity is impedance magnitude normalized by frequency and the magnetic susceptibility for free space. The apparent resistivity and phase are related through a Hilbert transform; the phase is proportional to the slope of the apparent resistivity curve on a log-log plot, relative to a baseline of 45 degrees (Vozoff, 1991).

Predicted values of the electric field can be computed from the measured values of the magnetic field (Vozoff, 1991). The coherence of the predicted electric field with the measured electric field is a measure of the signal-to-noise ratio, which is displayed as a function of frequency in the E-predicted coherency plots. Coherency values lie between 0 and 1 , where values at 0.5 denote signal levels equal to noise levels.

Several soundings were recorded at each station. The best sounding from each station is presented (Appendix A) and used in subsequent modeling of the data. The unedited data presented here are not rotated to the local geologic strike, but are fixed at specific azimuths as acquired in the field (Table 2). The ExHy mode is the nominal TM, and the EyHx the TE mode. Tensor data are calculated in the Imagem software (Geometrics, 2000). For each station, three separate panels are displayed in Appendix A: (1) Apparent resistivity, (2) Impedance phase, and (3) Coherency. 
Electronic data are available upon request in two formats: Geometrics Z Impedance files

(Geometrics, 2000; Appendix A) and the Electronic Data Interchange (EDI), which was established in 1987 by the Society of Exploration Geophysicists (SEG) as a standard format for the interchange of MT data (Wright, 1988).

\section{2-D Inverse Modeling}

Before modeling, impedance tensor data along each profile were rotated such that the $\mathrm{E}$ and $\mathrm{H}$ fields were approximately parallel and perpendicular to the regional geologic strike in the area. Based on the trends of faulting and geologic structures in these valleys, as well as depth to basement maps derived from gravity data, we chose our profiles in most cases to run roughly perpendicular to the geologic strike. Based on the 2-D nature of the geologic structures in all three valleys, we were fairly certain that we were working in 2-D environments. However, in some cases 3-D effects in the data were likely. Once mathematically rotated, spurious data and data with coherencies less than 0.75 were removed.

Dimensionality of each profile was determined by inspection of the data and dimensional analysis was performed if 3-D effects were suspect (Marti et al., 2005). Even in the presence of 3-D effects, 2-D modeling of the TM mode has been shown to be a robust approach (Wannamaker and others, 1984). We compute 2-D inverse models from the TE, TM, and TE+TM mode data using the conjugate gradient, finite-difference inversion of Rodi and Mackie (2001) for a range of starting models with many variations of regularization and smoothing parameters (Geosystem, 2005). We ran inversions both with and without topography, and we determined that the topography, which was fairly modest along each profile, did not affect the model results. Our preferred starting model along each profile used a $100 \mathrm{ohm}$-m half-space that included the topography. Other starting models were used to test model sensitivity and the depth of investigation. The primary criteria for choosing final models included the goodness of fit of the model response to the data as reported by the root mean square (RMS), the lack of artifacts in the model not supported by the data, and geological reasonableness of the model. RMS is commonly used to express the misfit between data and the model response. Misfits are normalized by the data error or the applied error floor. Misfits less than 1 fit the data to within the error bounds used in the inversion.

The AMT data on each profile are also displayed in pseudosection format with distance on the horizontal axis and period, the inverse of frequency, on the vertical axis (for example, see 
Figure 4). As frequency is a non-linear proxy for depth, pseudosections represent qualitatively the variation of apparent resistivity and phase with depth. The calculated apparent resistivity and phase from the inverse model response is displayed for comparison and is used to judge the goodness of fit. Our preferred models represent the most robust results along each line using the cleanest data. Although the depth of exploration varies as a function of resistivity and frequency, we are showing a constant depth of investigation throughout each section.

\section{AMT Surveys and Results}

This section discusses details of each AMT survey as well as the 2-D models along each line. Two separate surveys were conducted in Spring Valley. In May 2006 we collected a total of four profiles (SVNF, SVNH, SVNI, SVNG) along the western margin of the valley (labeled F, H, I, $\mathrm{G}$ respectively, in Figure 1). In June 2006, we collected four more profiles (SVNM, SVNK, SVNL, SVNJ) along the eastern margin of southern Spring Valley (labeled M, K, L, J on Figure 1). In October 2006, we collected three profiles in Snake Valley (SNKA, SNKB, SNKC, Figure 1). Finally, in April 2007, we moved further south and collected two profiles in Three Lakes Valley (TLVA, TLVC, Figure 2). A description of each AMT profile is provided in Table 1, and individual sounding location information is contained in Table 2.

Overall, the AMT 2-D models define range-front and inter-basin faults, basin-fill alluvium, volcanic rocks, and carbonate/clastic rocks.

\section{Spring Valley}

Profiles SVNF, SVNH, SVNI- Schell Creek Range

Profiles F, H, and I were located in the western-central region of the valley and extended from the Schell Creek Range into the valley (Figure 1). Power transmission lines run east-west across Spring Valley several kilometers to the north of Profile H. Anthropomorphic noise, such as power lines, power generators, moving vehicles and trains, produce noise mainly affecting frequencies above $1 \mathrm{~Hz}$, including the AMT observation frequency band. Data along each profile were noisy, despite the observation that the only known source of noise was the power lines several kilometers away.

The TE mode data were consistently noisier than those of the TM mode. Analysis of the rotational invariant parameters of the impedance tensor proposed by Weaver and others (2000) was 
used to establish a classification of dimensionality associated with the measured data taking into account data errors (Marti and others, 2005; Ester Falgás Parra, personal communication). The data were determined to be quasi-1D in character, where structure varies slowly from that of a layered Earth. A 2-D Earth assumes that there is no variation within the strike direction. Faulted structures can be strongly 2-D or quasi-1D depending on the offset. In either case, a 2-D inversion strategy is justified. We show the preferred 2-D inverse models for Profiles F, H, and I (Figures 38) computed from the TM mode data. For the most part, equivalent models resulted when using the TE + TM mode, with a slightly higher RMS fit.

In western-central Spring Valley, the range front fault on the eastern side of the Schell Creek Range is well defined on all three profiles (Figures 3, 5, 7) and separates more resistive basement to the west from basin fill to the east. The models appear to define the shape of the valley and several inter-basin faults represented by resistivity contrasts can be delineated throughout the sections. We observe more conductive basin fill sediments along Profile H (Figure 5) than we do along profile $\mathrm{F}$ to the north and profile I to the south.

\section{Profile SVNG- Fortification Range}

Profile G was located in southwestern Spring Valley and extended from the Fortification Range east into the valley (Figure 1). Data along this profile were fairly noisy. According to the same dimensionality analysis and reasoning that was applied to Profiles F, H, and I, we can justify 2-D modeling here and computed our preferred 2-D model from the TM mode data using a 100 ohm-m starting space with topography (Figures 9,10).

The resistivity structure along Profile G shows the opposite trend in resistivity toward the east than was observed along Profiles F, H, and I. Here we observe a more conductive structure on the west juxtaposed by more resistive 'basin fill' to the east. Profile G originates very close to outcrops of tuff breccia, so the west end of the profile is likely located in the volcanic source region of the Fortification Range. The model likely shows a range front fault between fractured volcanic rocks to the west, likely part of the Indian Peak Caldera Complex (Best and others, 1989), and more consolidated and, therefore, resistive volcanic rocks to the east into the valley.

\section{Profiles SVNM, SVNK, SVNL, SVNJ- Southern Snake Range}

We collected four additional AMT profiles near the margin of the southern Snake Range in southeastern Spring Valley. Three of these profiles (SVNM, SVNK, SVNL) originated in the 
Snake Range and extended west into the valley (Figure 1). There were no obvious sources of noise along these profiles. Profiles K, L, and M are oriented roughly perpendicular to the north-south geologic trend of the valley and the Snake Range, and we rotated the data along each profile such that the EM fields are oriented parallel and perpendicular to the range-front. We computed our preferred 2-D inverse models along each of these profiles from the TM mode data using a 100 ohm-m starting model with topography (Figures 11-16).

Profile $\mathrm{M}$ originated furthest east into the Snake Range, and the resulting model clearly shows a resistivity contrast likely in the location of a range-front fault separating resistive carbonate rocks of the Snake Range to the east with more conductive alluvial fill to the west (Figure 11). This contrast is less pronounced on Profile K (Figure 13) where the profile does not extend as far eastward into the range, however, a resistivity contrast at the east end of the line at an elevation of 1400 m likely reflects the valley floor at this eastern margin. Profile L (Figure 15) maps two distinct carbonate bodies in the upper few hundred meters of the surface. These resistive structures ( 500 ohm-m) are very similar to carbonate bodies observed along Profile A (Figure 1), $1 \mathrm{~km}$ to the north (McPhee and others, 2006).

The fourth profile (SVNJ) extended roughly north-south across a pass between the southern Snake Range and the Limestone Hills (Figure 1). Profile $\mathrm{J}$ is unique in that it trends oblique to the assumed regional geologic. Further work is planned in this pass region between Spring Valley and Hamlin Valley; modeling will be based upon both past and future data. Data acquired to date is shown in pseudosection format (Figure 17).

\section{Snake Valley}

Profiles SNKA, SNKB, SNKC

Three AMT profiles (SNKA, SNKB, SNKC) were collected near the western margin of southern Snake Valley (Figure 1). These profiles extended into the range in the west and eastward into Snake Valley. A small north-south power line ran across the middle of SNKA (at a distance $\sim 2400 \mathrm{~m}$ in Figure 18). This power line continued south and cut across SNKB at a distance 3600 m (Figure 20) and was several kilometers away from the eastern end of SNKC. The power line was not a problem for stations at a distance greater than $200 \mathrm{~m}$. The data in the high-frequency band (800-92,000 Hz), however, were noisy on all three profiles. After we completed the survey, we discovered that the transmitter that we were using to augment the natural source in the high- 
frequency band was not operating correctly; only one of the two magnetic dipoles was transmitting. Consequently, we had to omit all of our high-frequency data. We computed 2-D models along each of these profiles using only the low-frequency data (10 Hz to $\sim 800 \mathrm{~Hz}$ ) and present only preliminary models here (Figures 18-23) computed from TM mode data. Consequently, values in the pseudosections from 100,000 to $1000 \mathrm{~Hz}$, and in the model from the surface to $150 \mathrm{~m}$, are artifacts of contouring. Because only the low-frequency data were used, the models are very smooth being more robust and with lower RMS misfits than models computed from TE+TM mode data or with more restrictive regularization parameters. Models along all three profiles used a starting half-space model of 100 ohm-m with topography.

The extremely smooth models of SNKA and SNKB (Figures 18 and 20) show deep resistive features likely associated with crystalline rocks of the Snake Range while SNKC shows distinctly different, more conductive structure at depth.

\section{Three Lakes Valley}

\section{Profiles TLVA, TLVC}

We collected our final two AMT profiles (TLVA, TLVC) in southwestern Three Lakes Valley, roughly $300 \mathrm{~km}$ south of Spring Valley and about $35 \mathrm{~km}$ northwest of Las Vegas (Figure 2). Both profiles ended approximately 100-200 m north of a major highway (Hwy 95). A power line ran parallel to the highway on the south side, about 200-400 m from the ends of our profiles. There were no other sources of noise, and we collected clean data along the entire length of the profiles. TLVA and TLVC originated near fractured carbonate outcrops and extended roughly southwest into the valley. These profiles ran roughly perpendicular to the known NW-SE trending faults in the region but were oblique to the topography (Figure 2). The Las Vegas Valley Shear Zone (Langenheim and others, 1998) is a major structural feature in the region, and it cuts NW-SE though this part of the valley. Our objective was to image this shear zone and other faults in the area.

Through inspection of both modes, data show structure to be smoothly varying (quasi-1D) in the valley and crossing a structural contact in the middle of both profile lines consistent with the 2-D assumption. As seen in the data and resulting models, structural variations are predominant on the northern end of line where the profile lines separate; line TLVA shows quasi-1D responses while a distinct 2-D response is apparent on line TLVC. Our preferred 2-D models resulted from 
TE+TM mode data using a 100 ohm-m starting model with topography (Figures 24-27). We ran several inversions using both the TM only and TE+TM mode data and found that the models resulting from the TE+TM mode data were more robust to varying parameters.

Models along TLVA and TLVC were consistent with each other as well as the local, outcropping geology. Both models image resistive (> $1000 \mathrm{ohm}-\mathrm{m}$ ) carbonate structures at the northeastern end of the profiles. In addition, the shear zone can be seen cutting through the center of both profiles (at $\sim 1000 \mathrm{~m}$ along TLVA and $~ 900 \mathrm{~m}$ along TLVC) juxtaposing more resistive carbonate rocks to the northeast with more conductive alluvial fill to the southwest. The higher RMS fit along TLVA (RMS = 5.4) was the result of one particularly noisy station, sounding \#23 (Figure 24), which we chose to keep, because the model was robust and remained essentially unchanged whether or not this station was included.

\section{Acknowledgments}

This study was performed in cooperation with the Southern Nevada Water Authority whose support is greatly appreciated. We are grateful to the many people that helped us in the field, including Bill Van Stone, Carter Roberts, Casey Collins, Eric Dano, Ester Falgás Parra, Frank Baird, Harvey Eastman, Jason Mace, Keith Pari, Kevin Graves, Melissa Cansdale, Paul Jahn, Ray Schuth, Rhonda Olsen, and Tobyn VanVeghten. We thank the staff of Geometrics for providing valuable and efficient field assistance, and we especially thank Gary Dixon, Jeff Johnston, and Ester Falgás Parra for contributing their expertise and advice. We also thank Dan Scheirer and Paul Bedrosian for their helpful reviews.

\section{References Cited}

Best, M.G., Christiansen, E.H., and Blank, R.H., Jr., 1989, Oligocene caldera complex and calcalkaline tuffs and lavas of the Indian Peak volcanic field, Nevada and Utah: Geological Society of America Bulletin, 101, p. 1076-1090.

Eberhart-Phillips, D., Stanley, W.D., Rodriguez, B.D. and Lutter, W.J., 1995, Surface seismic and electrical methods to detect fluids related to faulting: Journal of Geophysical Research, 100, p. 12,919-12,936.

Geometrics, 2000, Operation Manual for Stratagem systems running IMAGEM, Ver. 2.16:

Geometrics, San Jose, California.

Geosystem, 2005, A guide to using WinGLink, Ver 2.07.05: Geosystem srl, Milan, Italy. 
Harrill, J.R., and Prudic, D.E., 1998, Aquifer systems in the Great Basin region of Nevada, Utah and adjacent states - summary report: U.S. Geological Survey Professional Paper, 1409A, 61p.

Keller, G.V., 1987, Rock and mineral properties, in Electromagnetic Methods in Applied Geophysics Theory: M.N. Nabighian, Ed., Society of Exploration Geophysicists, Tulsa, Oklahoma, v.1, p. 13-51.

Keller, G.V., 1989, Electrical properties, in Carmichael, R.S., Ed., Practical handbook of physical properties of rocks and minerals: CRC Press, Boca Raton, Florida, p. 359-427.

Langenheim, V.E., Grow, J., Miller, J., Davidson, J.D., and Robison, E., 1998, Thickness of Cenozoic deposits and location and geometry of the Las Vegas Valley Shear Zone, Nevada, based on gravity, seismic-reflection, and aeromagnetic data, U.S. Geological Survey Open-File Report 98-576, 32 p.

Mankinen, E.A., Roberts, C.W., McKee, E.H., Chuchel, B.A., and Morin, R.L., 2007, Geophysical data from Spring Valley to Delamar Valley, east-central Nevada: U.S. Geological Survey OpenFile Report 2007-1190, 43 p.

Mankinen, E.A., Roberts, C.W., McKee, E.H., Chuchel, B.A., and Moring, B.C., 2006, Geophysical data from the Spring and Snake valleys area, Nevada and Utah: U.S. Geological Survey Open-File Report 2006-1160, 42 p.

Marti, A., Queralt, P., Jones, A.G., and Ledo, J., 2005, Improving Bahr’s invariant parameters using the WAL approach, Geophysical Journal International, 163, 38-41.

McPhee, D.K., Chuchel, B.A., and Pellerin, L, 2006, Audiomagnetotelluric data from Spring, Cave, and Coyote Spring Valleys, Nevada: U.S. Geological Survey Open-File Report 2006-1164, 41 p.

Nesbitt, B.E., 1993, Electric resistivities of crustal fluids, Journal of Geophsyical Research, 98, p.4301-4310.

Palacky, G.J., 1987, Resistivity characteristics of geologic targets, in Electromagnetic Methods in Applied Geophysics Theory: M.N. Nabighian, Ed., Society of Exploration Geophysicists, Tulsa, Oklahoma, vol. 1, p. 53-129.

Plume, R.W., 1996, Hydrogeologic framework of the Great Basin region of Nevada, Utah and adjacent states: U.S. Geological Survey Professional Paper 1409-B, 64p.

Rodi, W., and Mackie, R. L., 2001, Nonlinear conjugate gradients algorithm for 2-D magnetotelluric inversion, Geophysics, 66, 174-187.

Scheirer, D.S., 2005, Gravity studies of Cave, Dry Lake, and Delamar Valleys, east-central 
Nevada: U.S. Geological Survey Open File Report, 2005-1339, 36p.

Telford, W.M., Geldart, L.P., and Sheriff, R.E., 1991, Applied Geophysics (2 ${ }^{\text {nd }}$ Edition):

Cambridge University Press, 790 p.

Vozoff, K., 1991, The magnetotelluric method, in Electromagnetic methods in applied geophysics:

M.N. Nabighian, Ed., Society of Exploration Geophysicists, Tulsa, Oklahoma, vol. 2, part B, p. 641-711.

Wannamaker, P.E., Hohmann, G.W., and Ward, S.H., 1984, Magnetotelluric responses of threedimensional bodies in layered earths: Geophysics, 49, 1517-1533.

Weaver, J.T., Agarwal, A.K., and Lilley, F.E.M, 2000, Characterization of the magnetotelluric tensor in terms of its invariants, Geophysical Journal International, 141, 321-336.

Wright, D.E., 1988, The SEG Standard for Magnetotelluric Data: presented at the Society of Exploration Geophysicists Annual Meeting, November. Available through http://www.geophysics.dias.ie/mtnet/docs/ediformat.txt.

Zonge, K.L. and Hughes, L.J., 1991, Controlled source audio-frequency magnetotellurics, in Electromagnetic methods in applied geophysics: M.N. Nabighian, Ed., Society of Exploration Geophysicists, Tulsa, Oklahoma, vol. 2, part B, p. 713-809. 


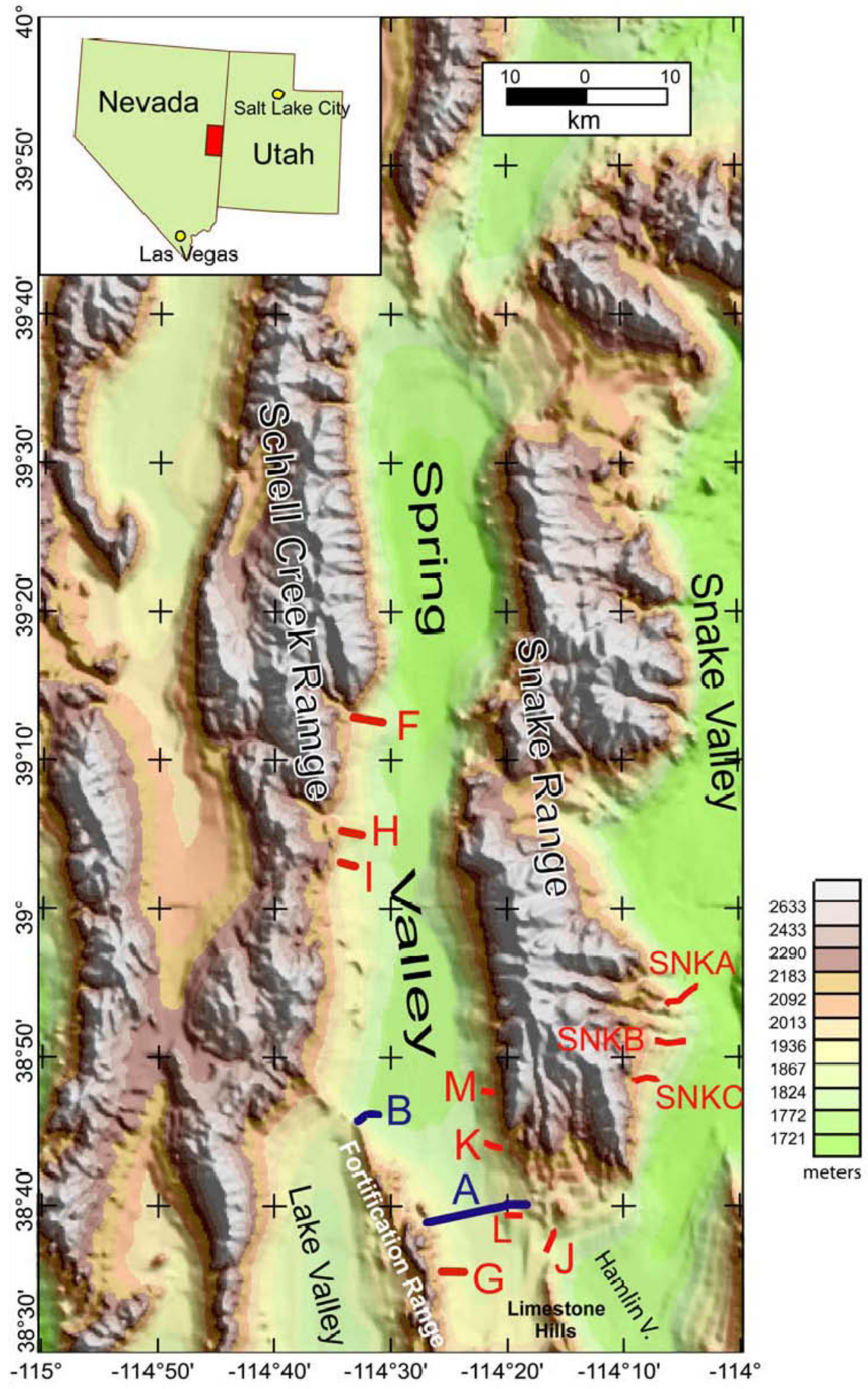

Figure 1. Topographic map of study area showing location of AMT profiles in Spring and Snake Valleys. Profiles A and B were collected in 2004 and are presented in McPhee and others (2006). 


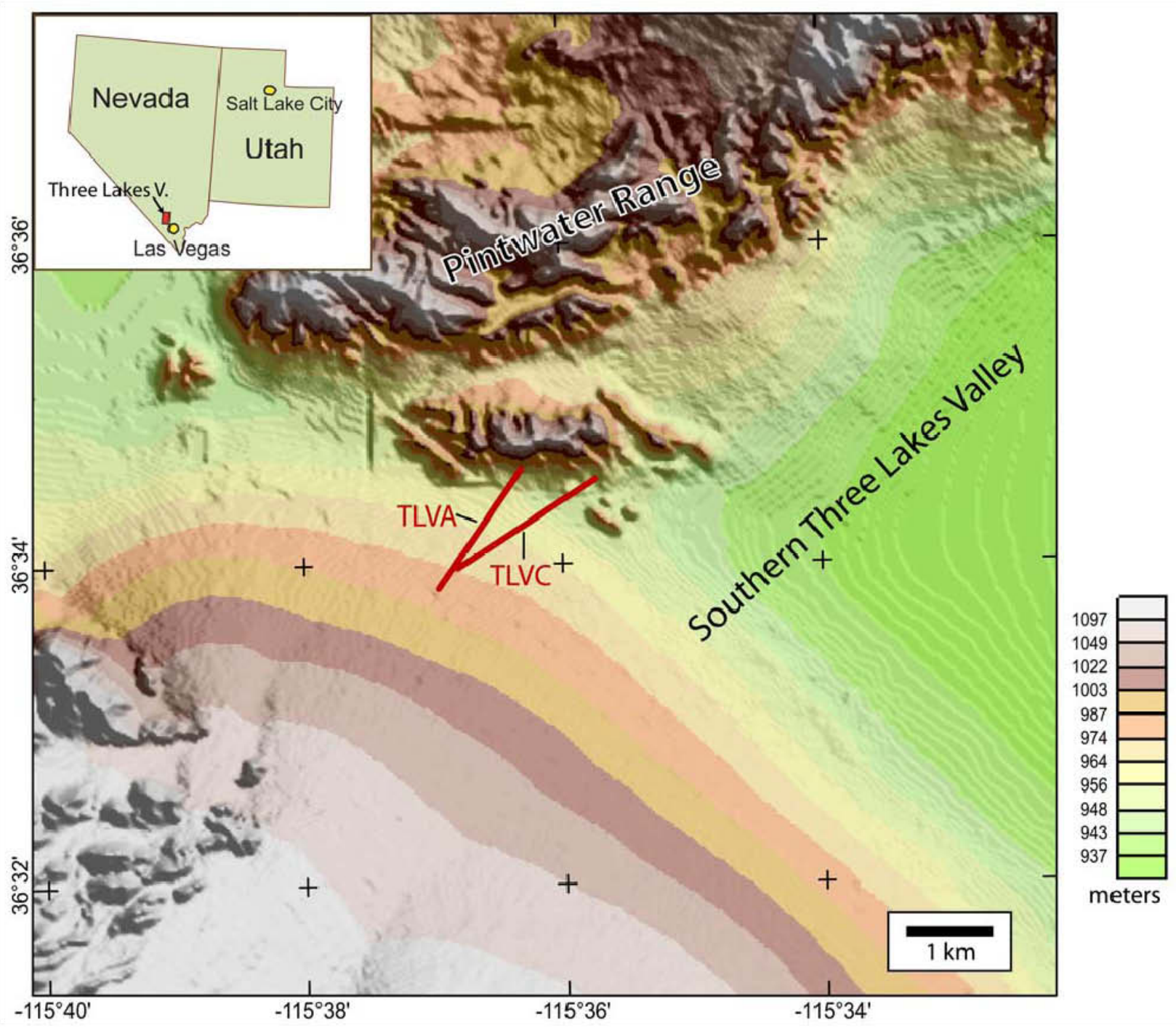

Figure 2. Topographic map of study area showing location of AMT profiles in southern Three Lakes Valley. 


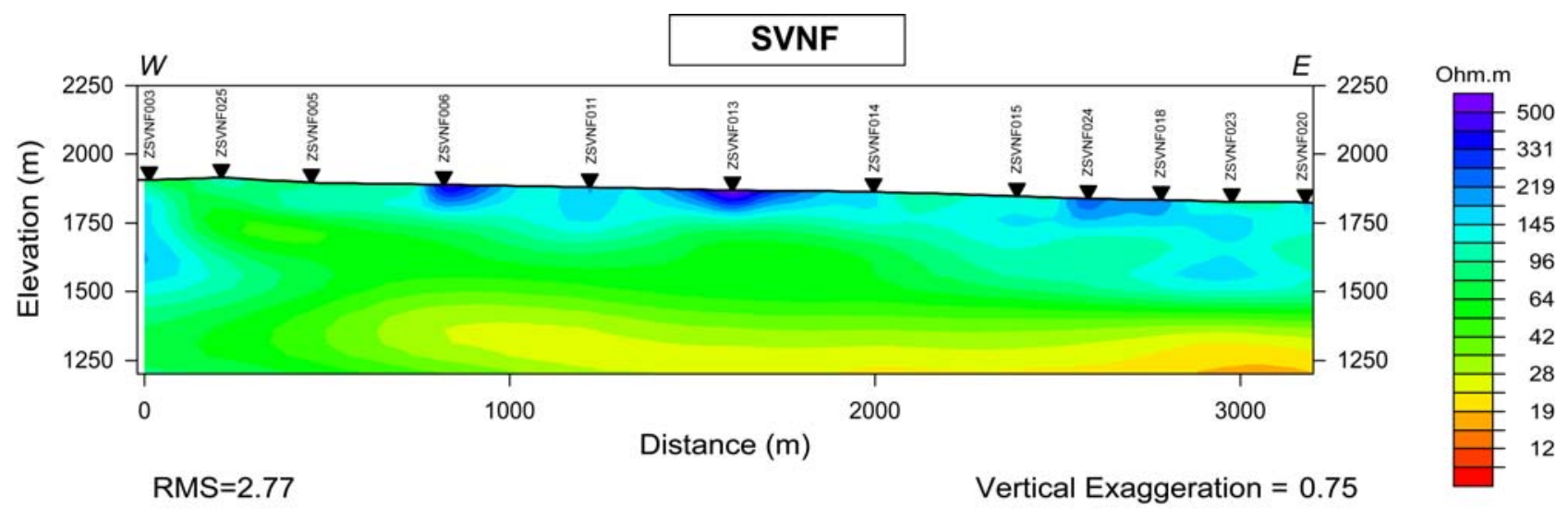

Figure 3. 2-D inverse model computed from the TM mode data along profile SVNF in Spring Valley. 


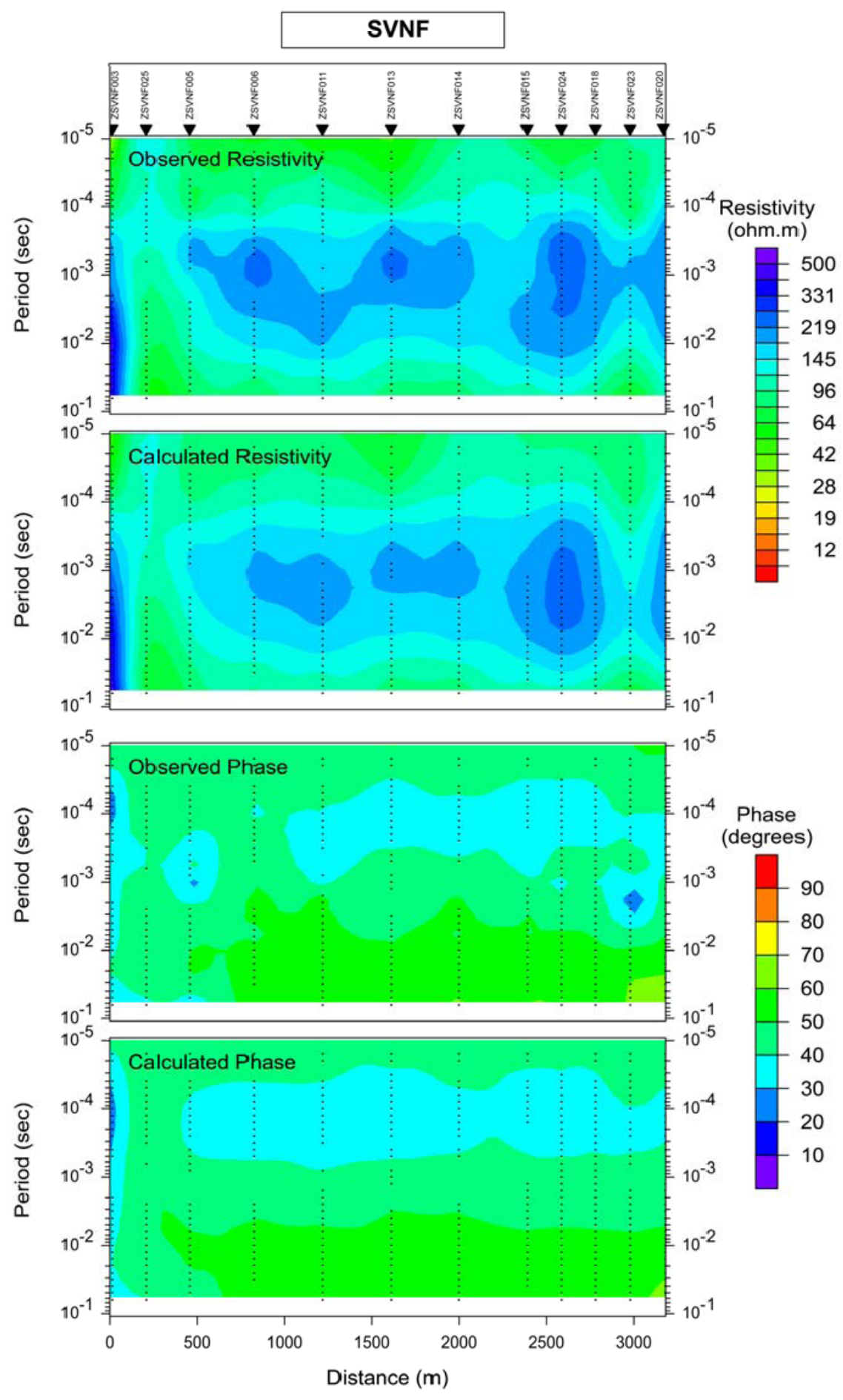

Figure 4. Pseudosections of observed data and model response for the apparent resistivity and phase along profile SVNF. Black dots show data points. 


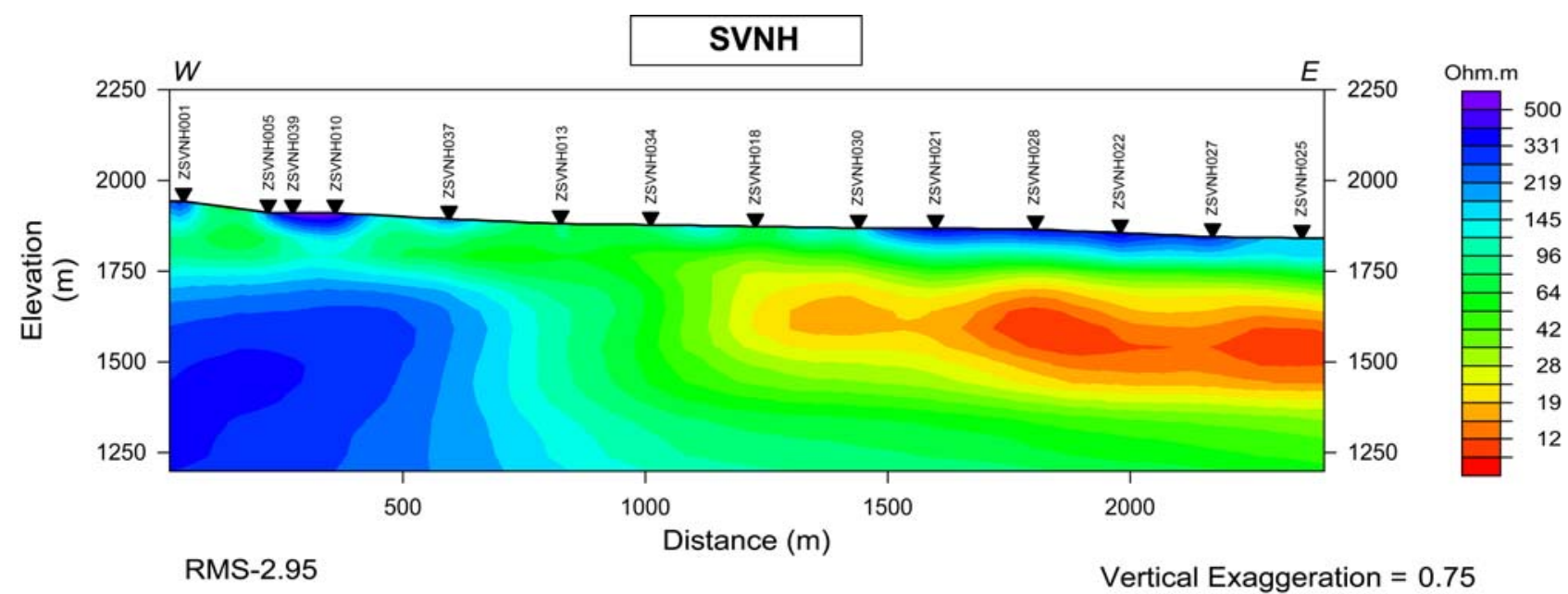

Figure 5. 2-D inverse model computed from the TM mode data along profile SVNH in Spring Valley. 


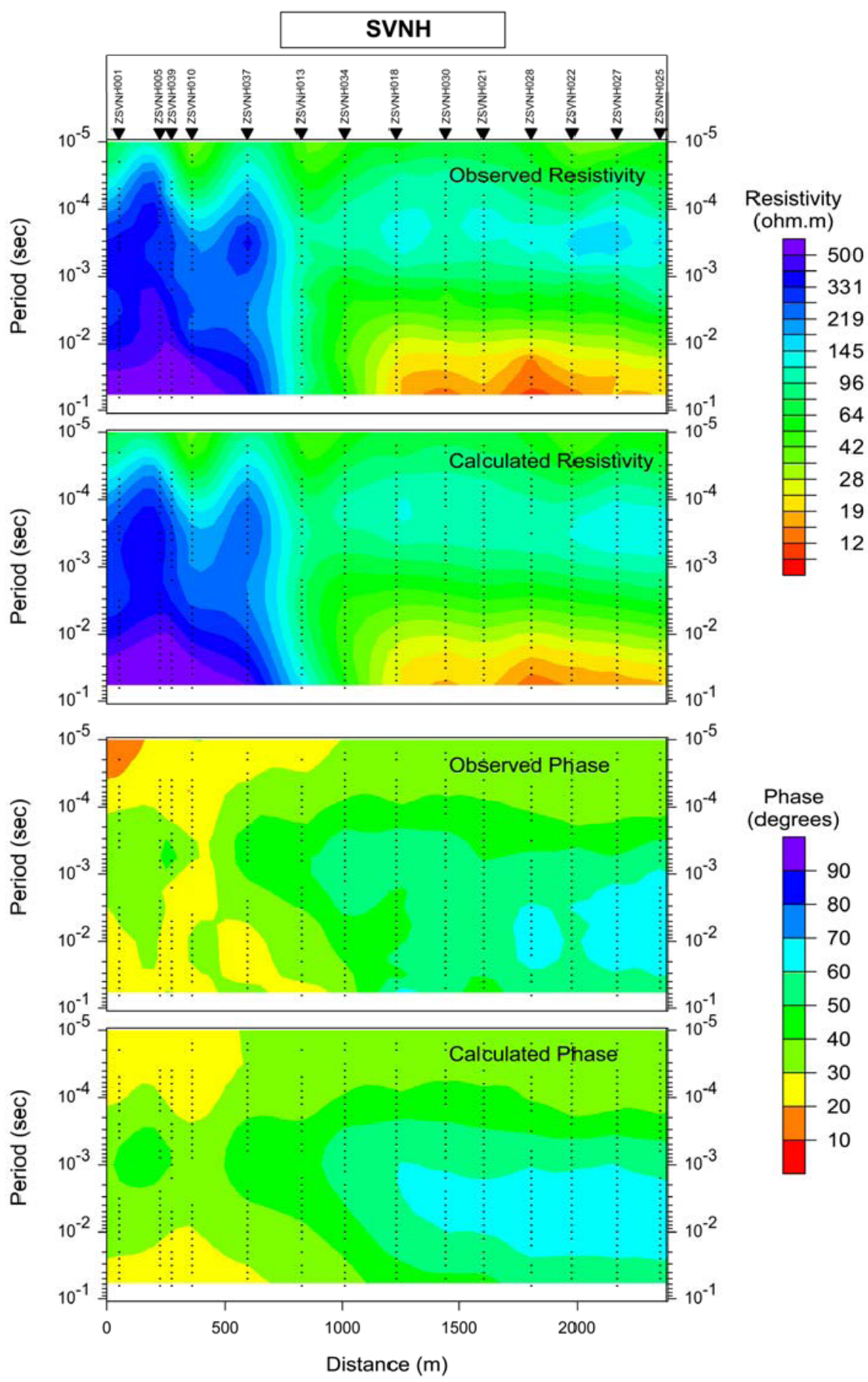

Figure 6. Pseudosections of observed data and model response for the apparent resistivity and phase along profile SVNH. Black dots show data points. 


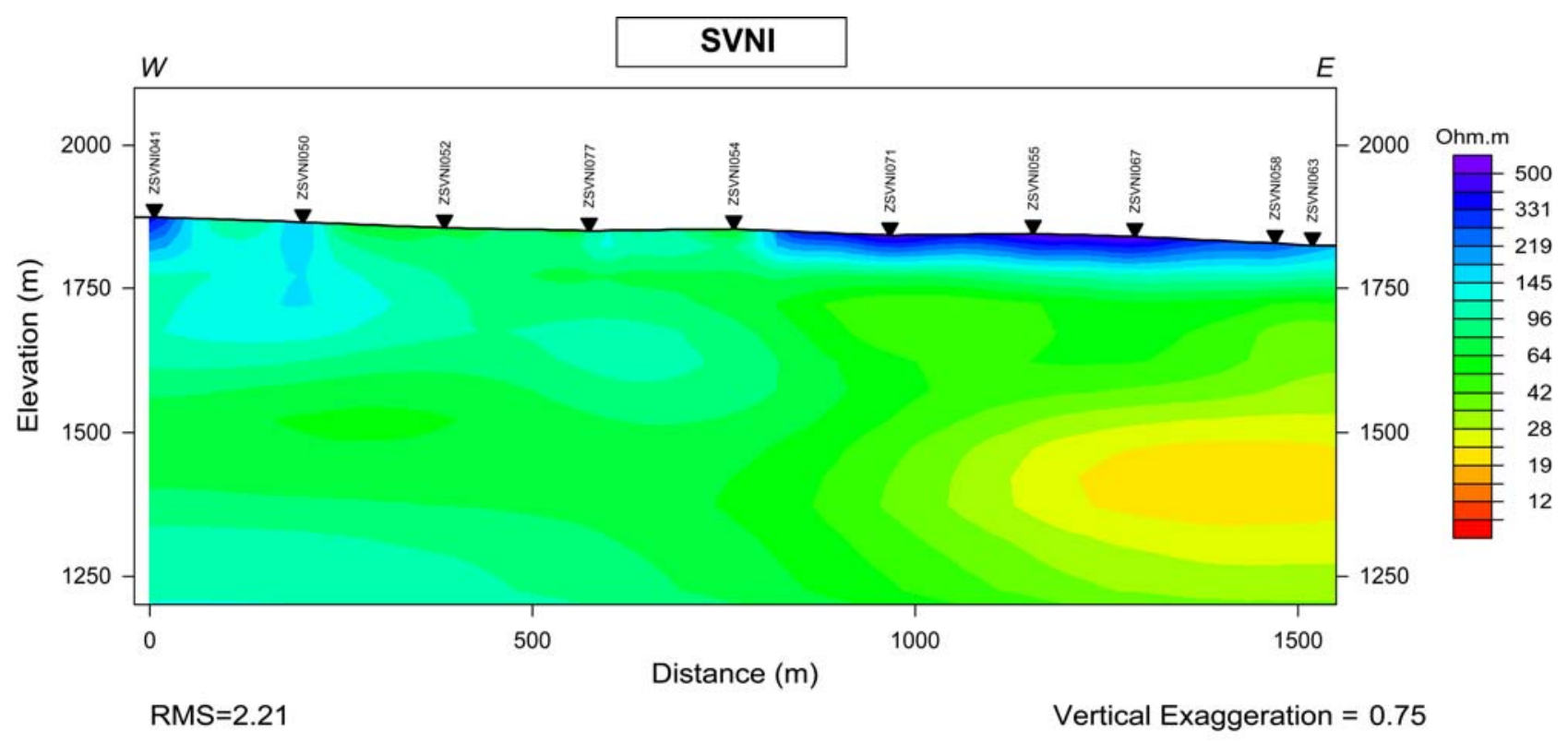

Figure 7. 2-D inverse model computed from the TM mode data along profile SVNI in Spring Valley. 


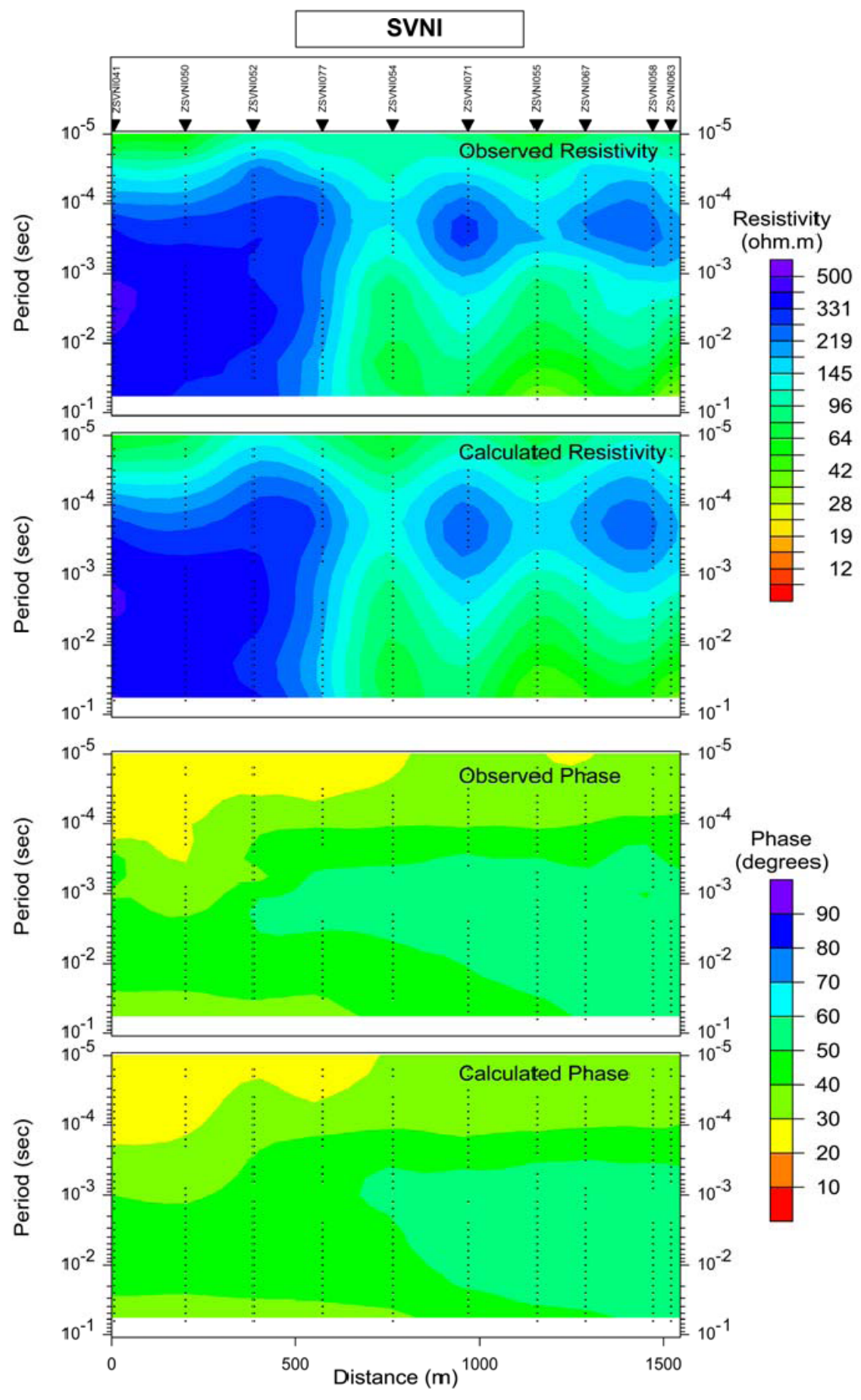

Figure 8. Pseudosections of observed data and model response for the apparent resistivity and phase along profile SVNI. Black dots show data points. 


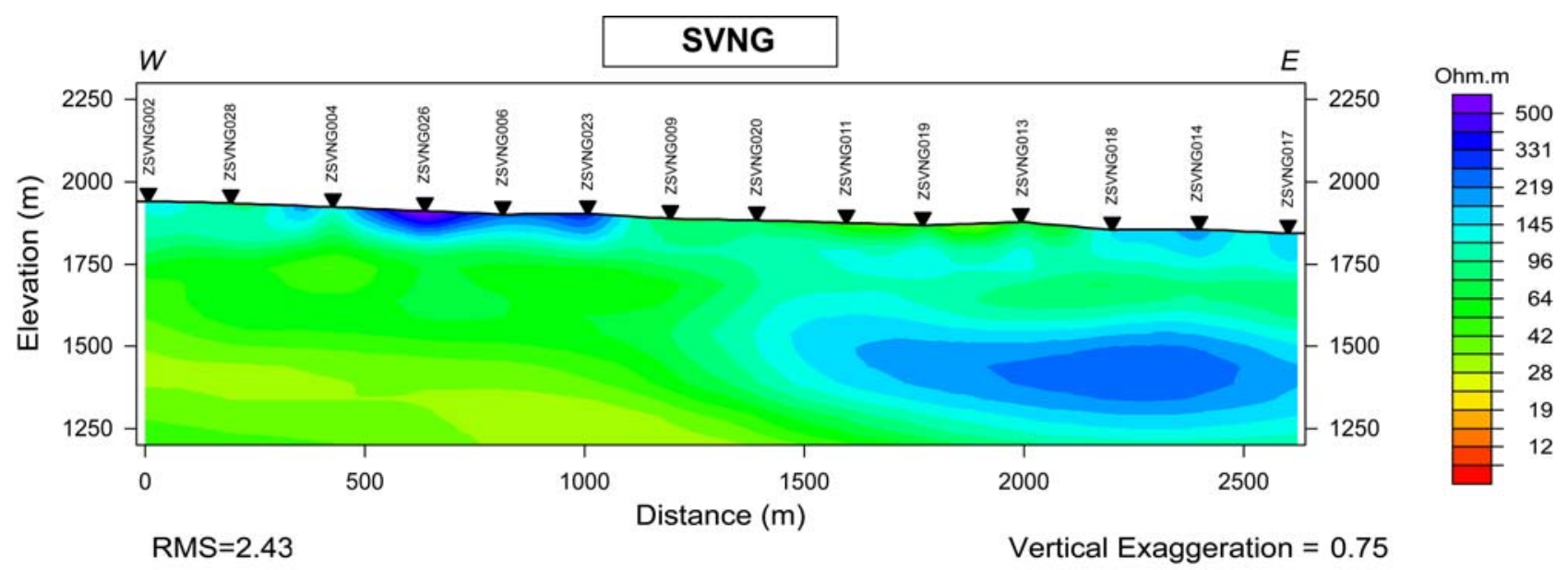

Figure 9. 2-D inverse model computed from the TM mode data along profile SVNG in Spring Valley. 


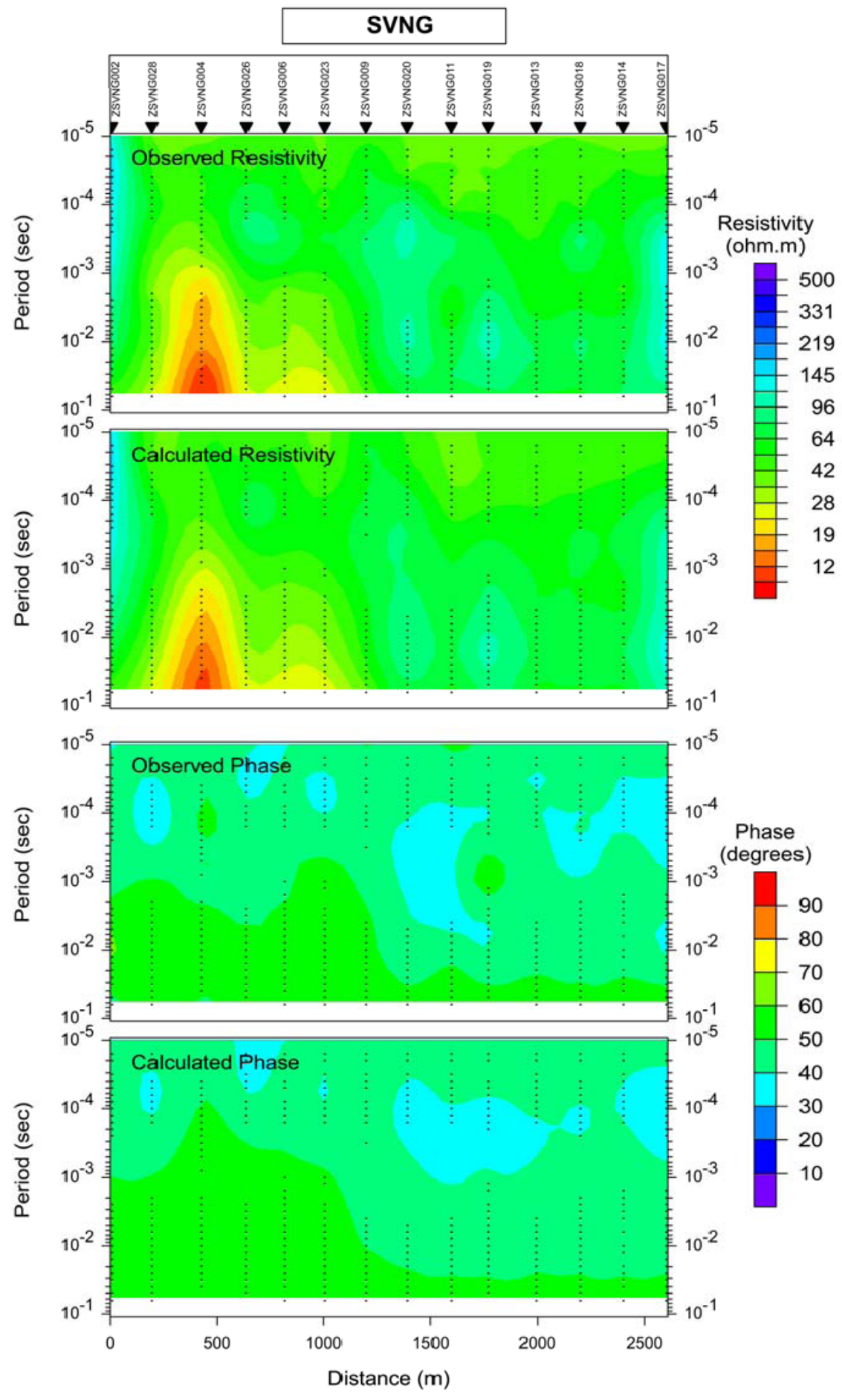

Figure 10. Pseudosections of observed data and model response for the apparent resistivity and phase along profile SVNG. Black dots show data points. 


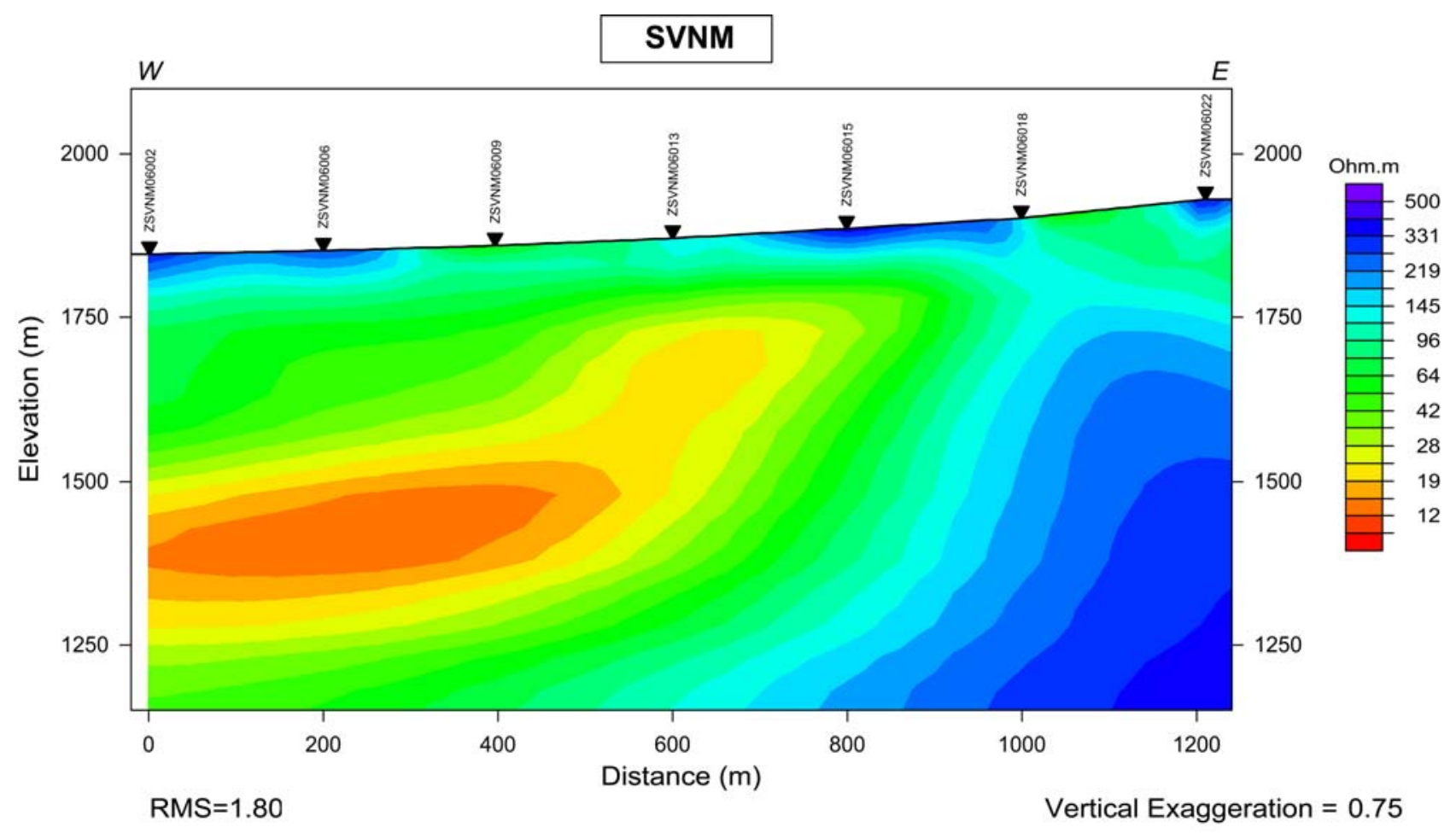

Figure 11. 2-D inverse model computed from the TM mode data along profile SVNM in Spring Valley. 


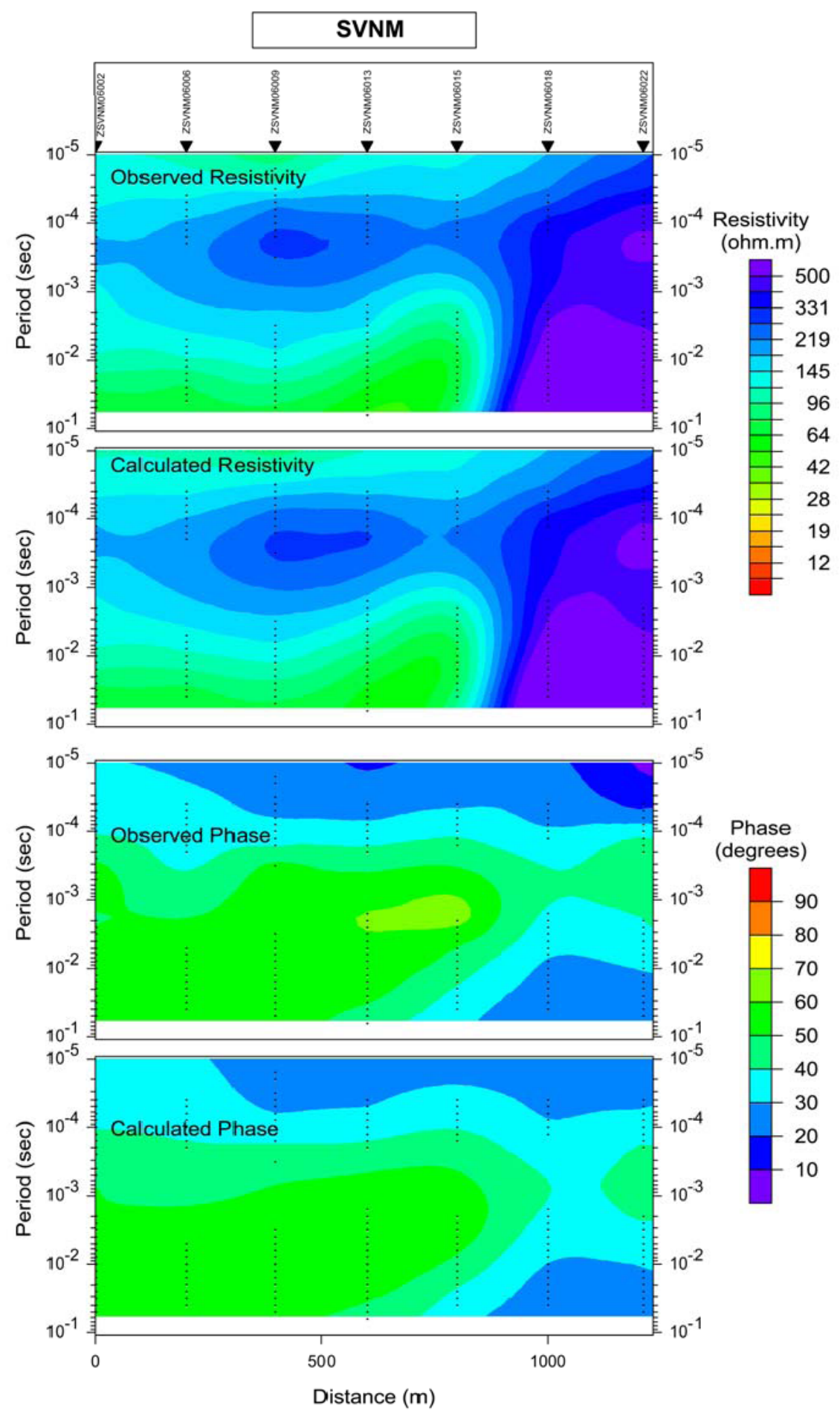

Figure 12. Pseudosections of observed data and model response for the apparent resistivity and phase along profile SVNM. Black dots show data points. 


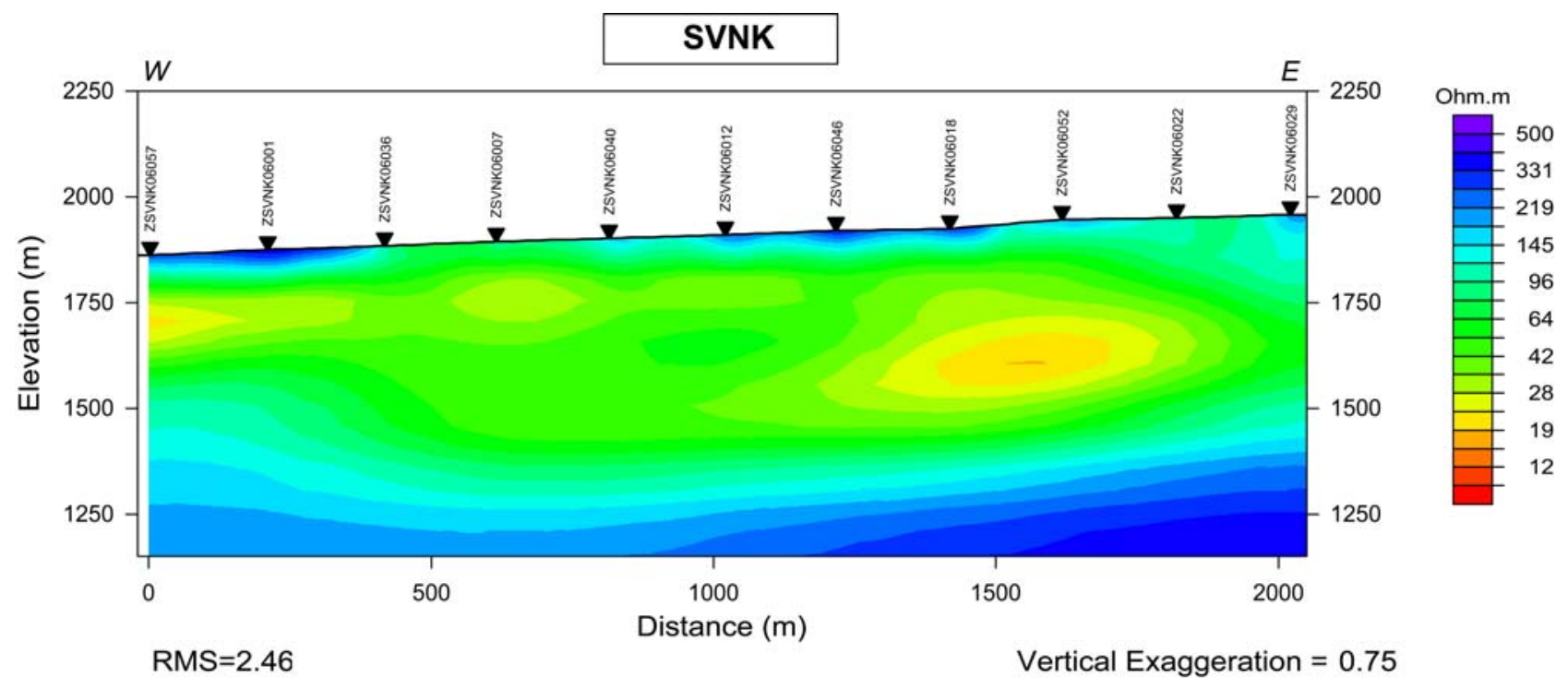

Figure 13. 2-D inverse model computed from the TM mode data along profile SVNK in Spring Valley. 


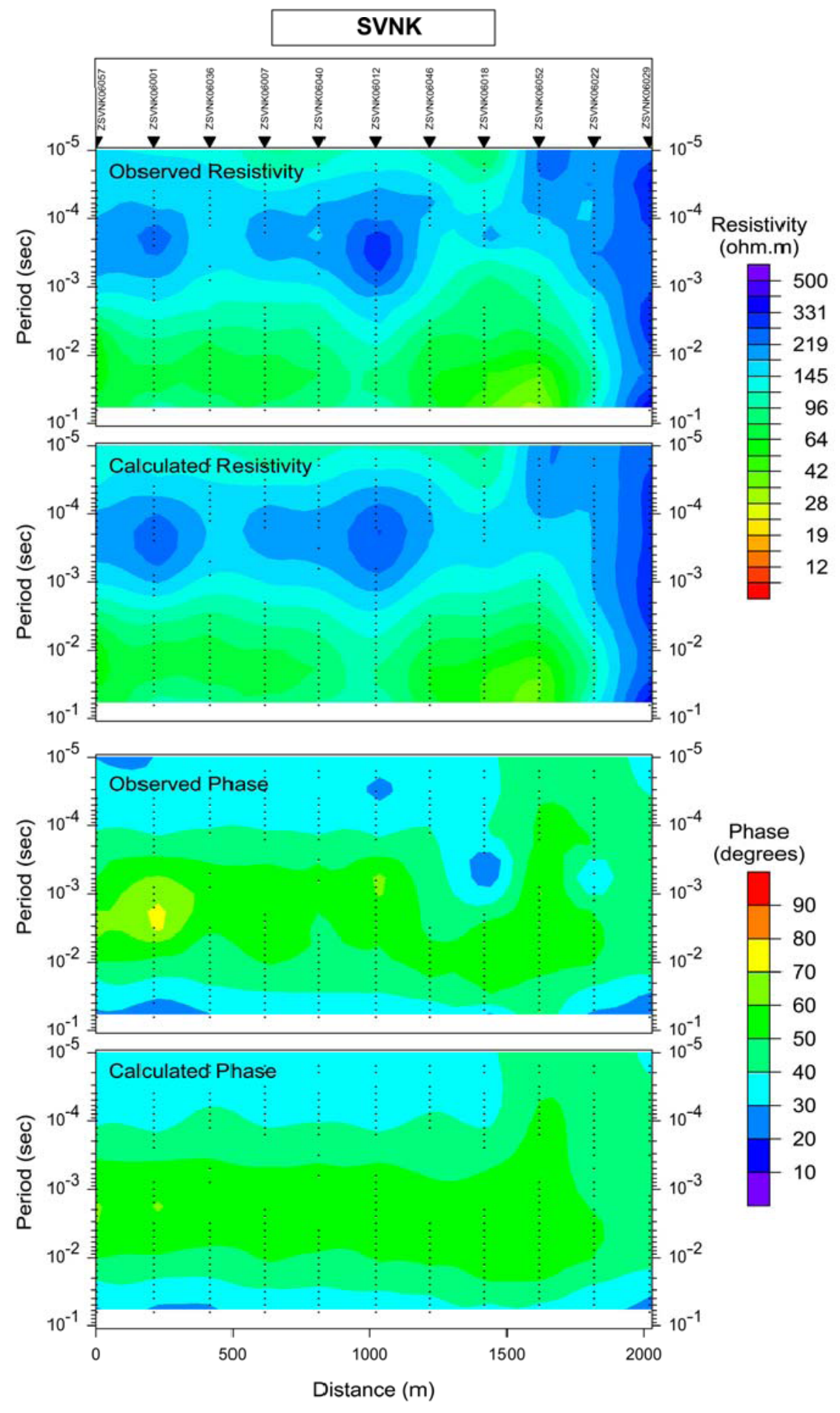

Figure 14. Pseudosections of observed data and model response for the apparent resistivity and phase along profile SVNK. Black dots show data points. 


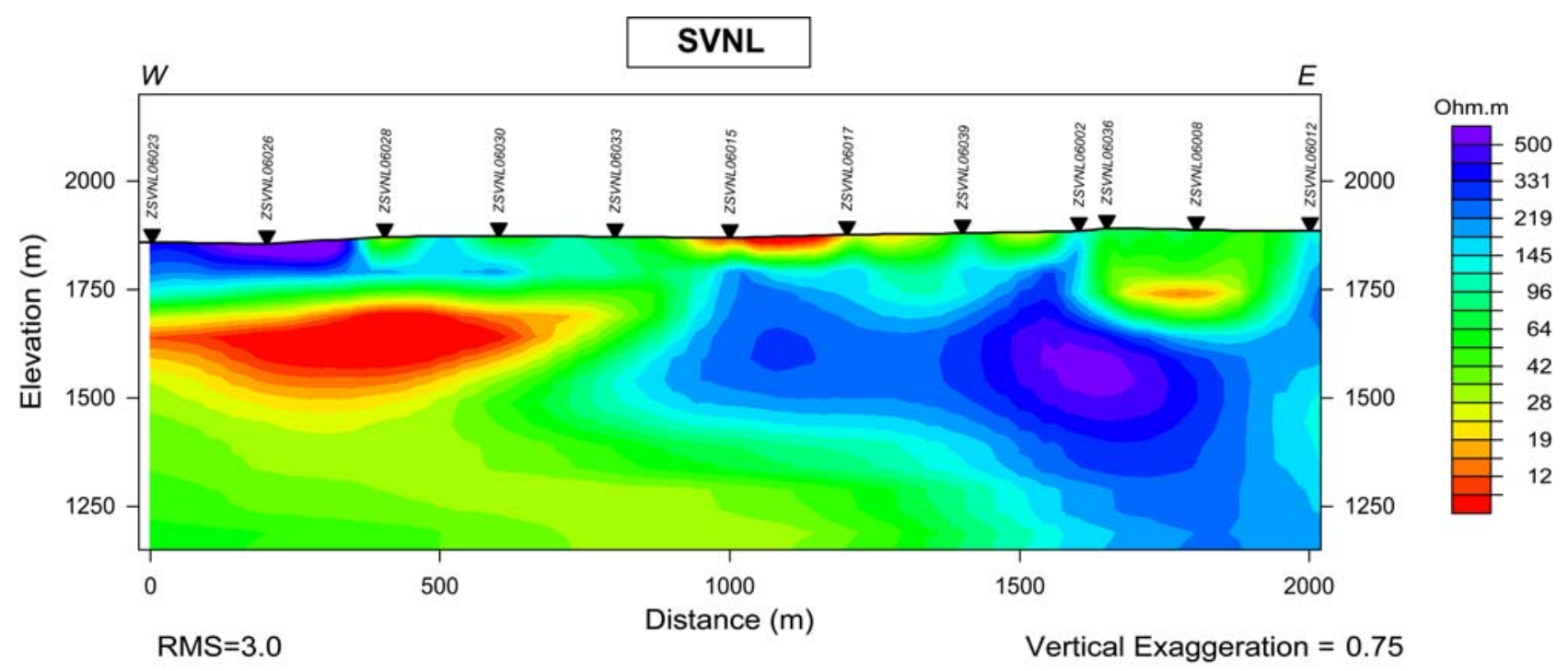

Figure 15. 2-D inverse model computed from the TM mode data along profile SVNL in Spring Valley. 


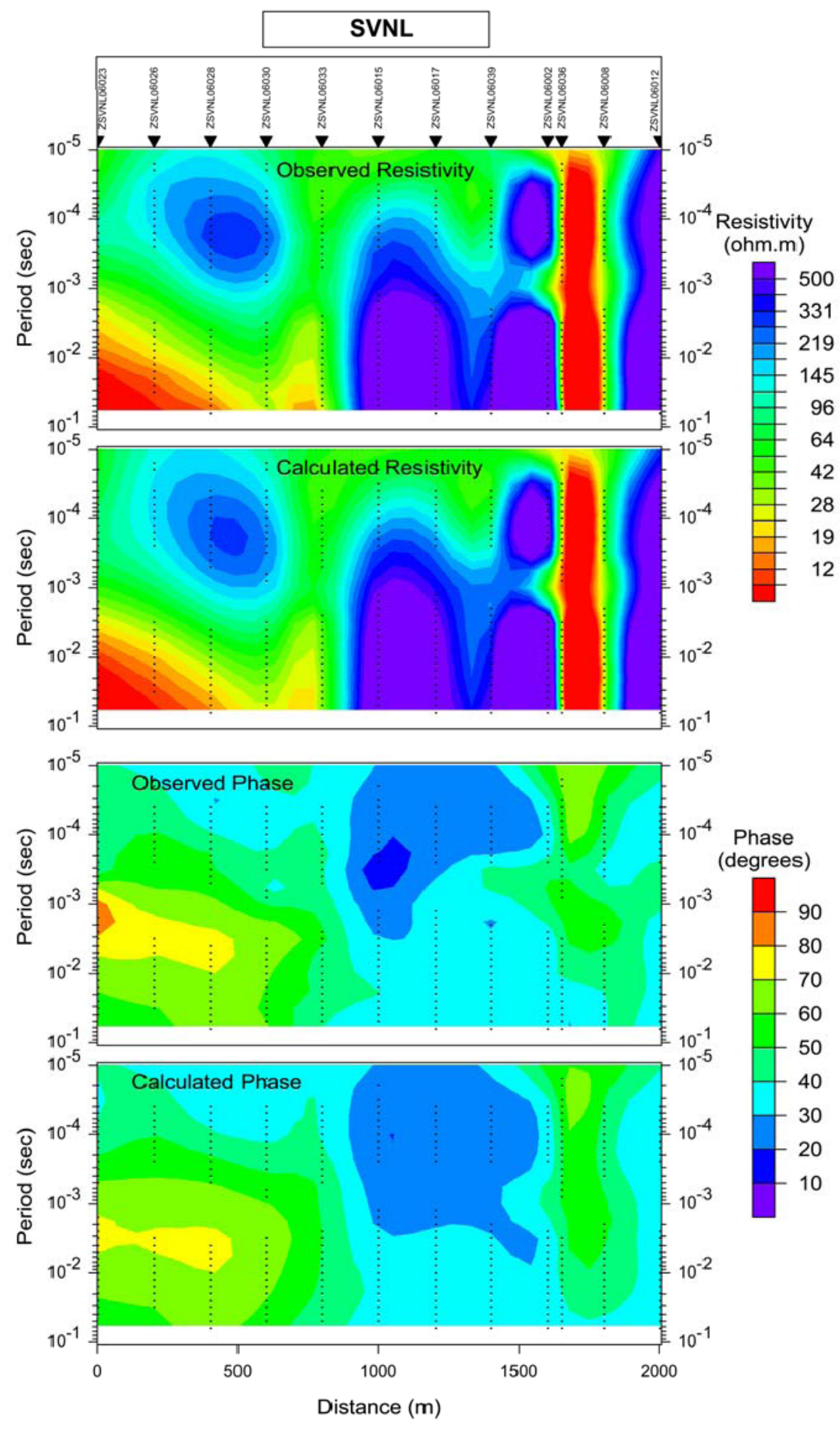

Figure 16. Pseudosections of observed data and model response for the apparent resistivity and phase along profile SVNL. Black dots show data points. 


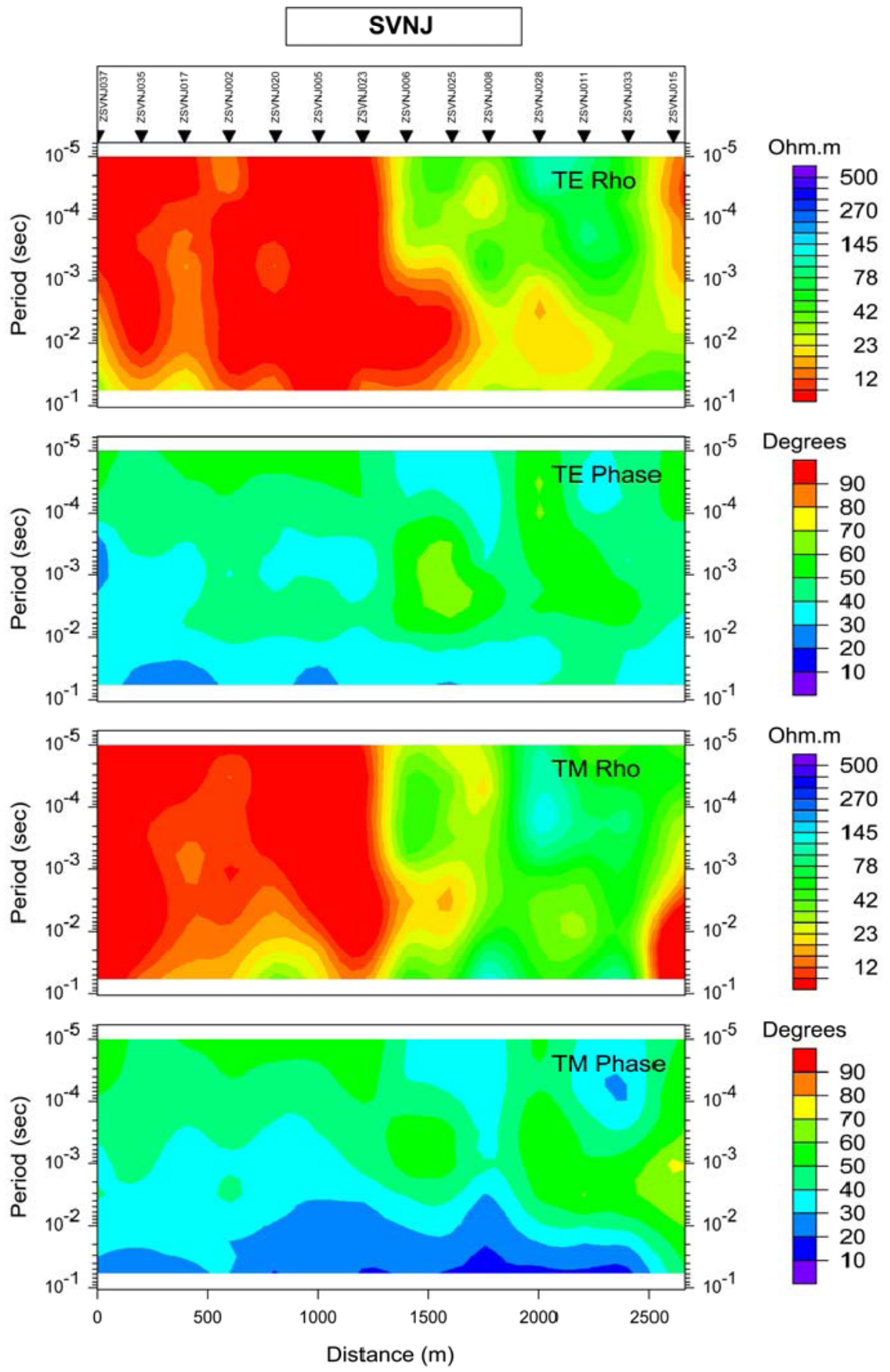

Figure 17. Pseudosections of observed data only for the TE and TM mode apparent resistivity and phase along profile SVNJ. 


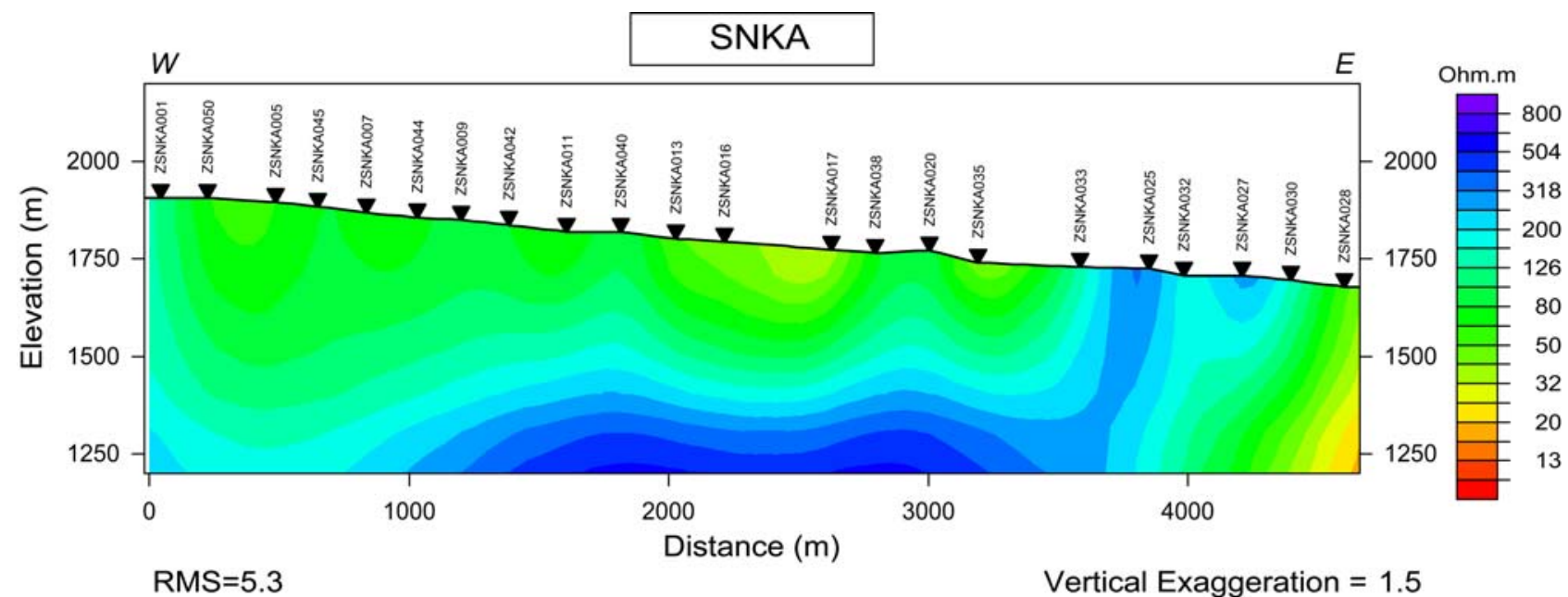

Figure 18. 2-D inverse model computed from the TM mode data along profile SNKA in Snake Valley. Note that resistivity scale is different from that used in Spring Valley models. 


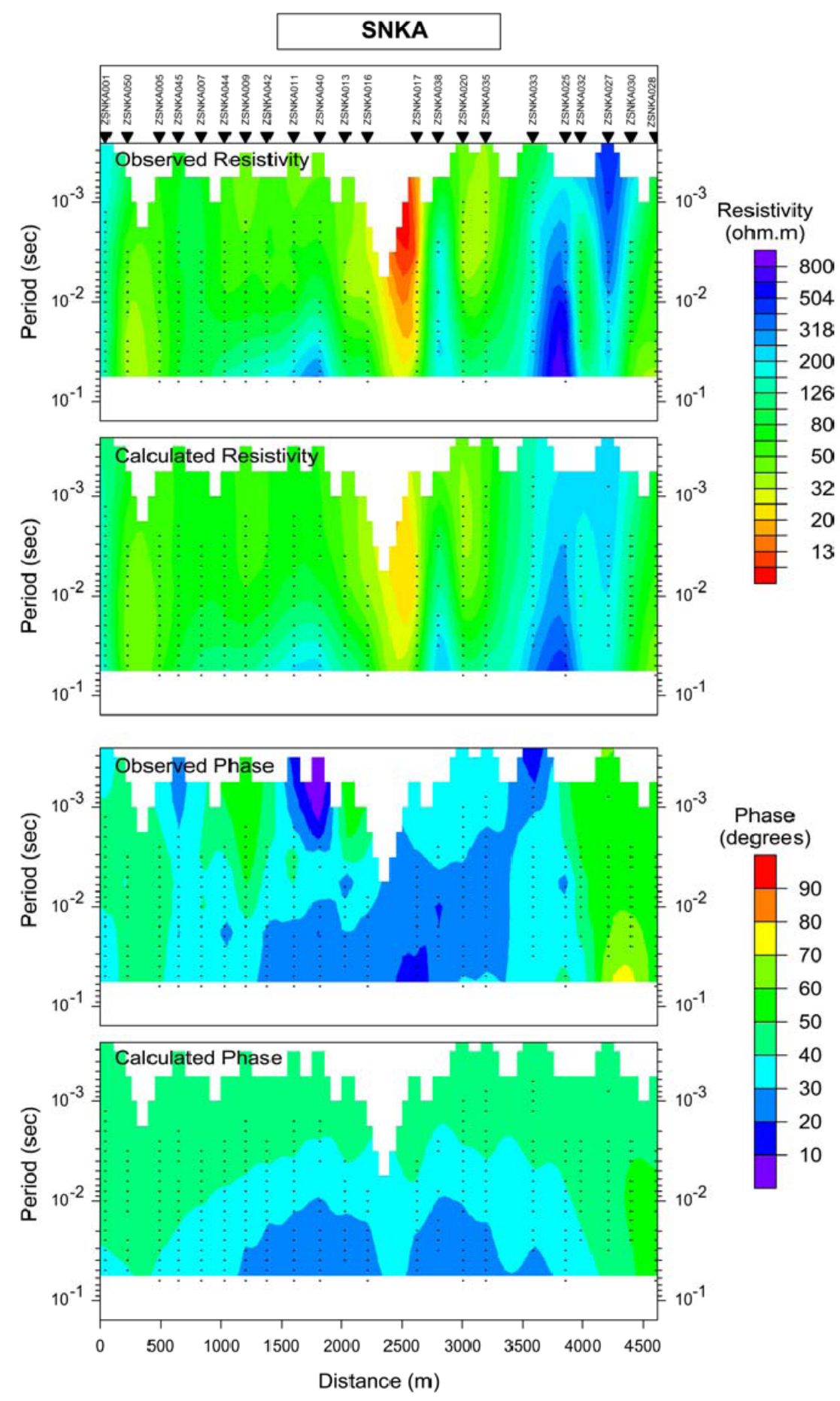

Figure 19. Pseudosections of observed data and model response for the apparent resistivity and phase along profile SNKA. Black dots show data points. 


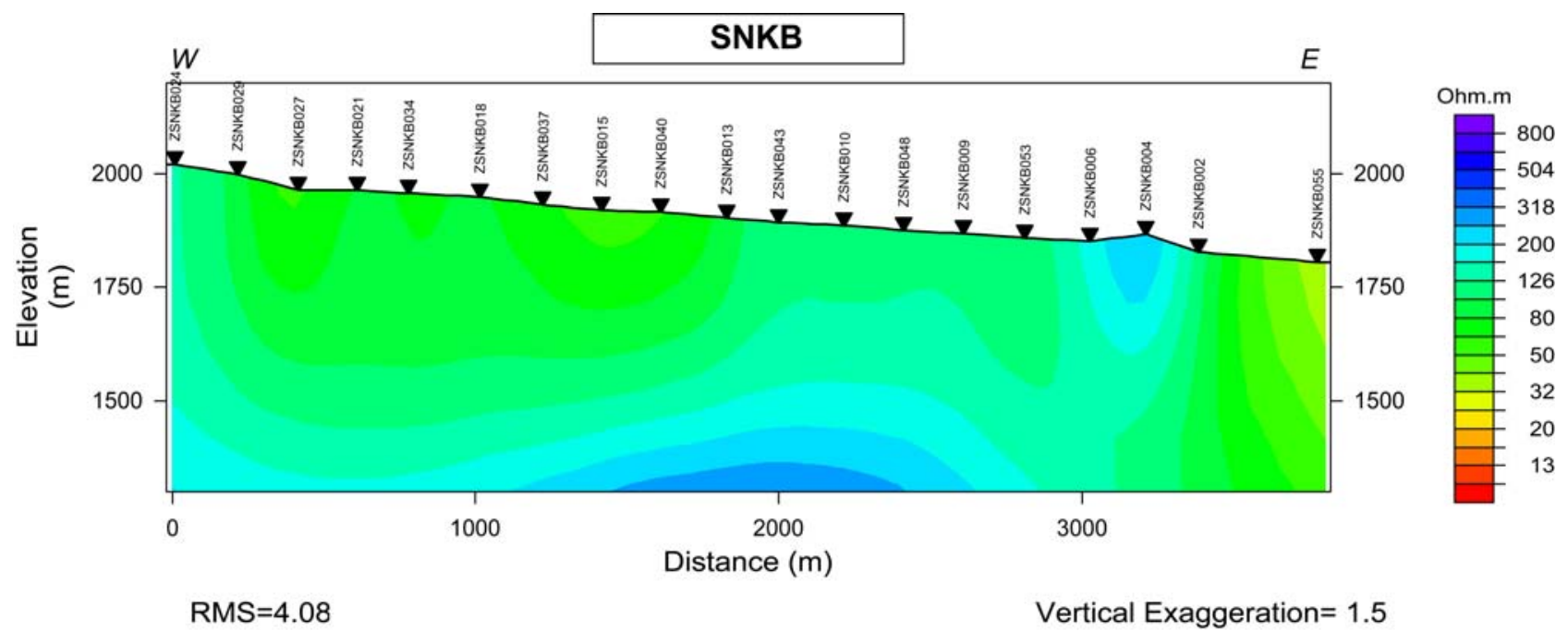

Figure 20. 2-D inverse model computed from the TM mode data along profile SNKB in Snake Valley. 

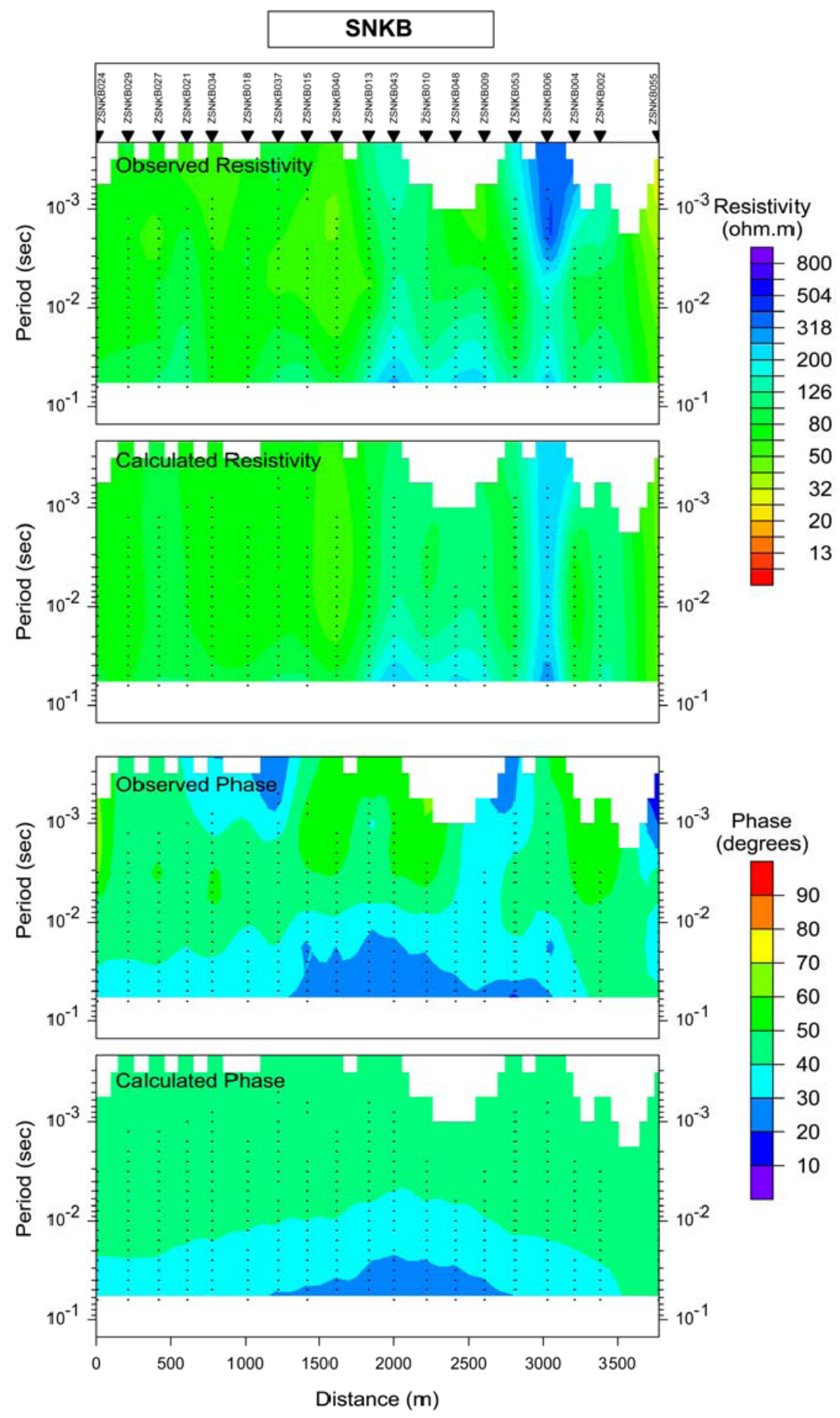

Figure 21. Pseudosections of observed data and model response for the apparent resistivity and phase along profile SNKB. Black dots show data points. 


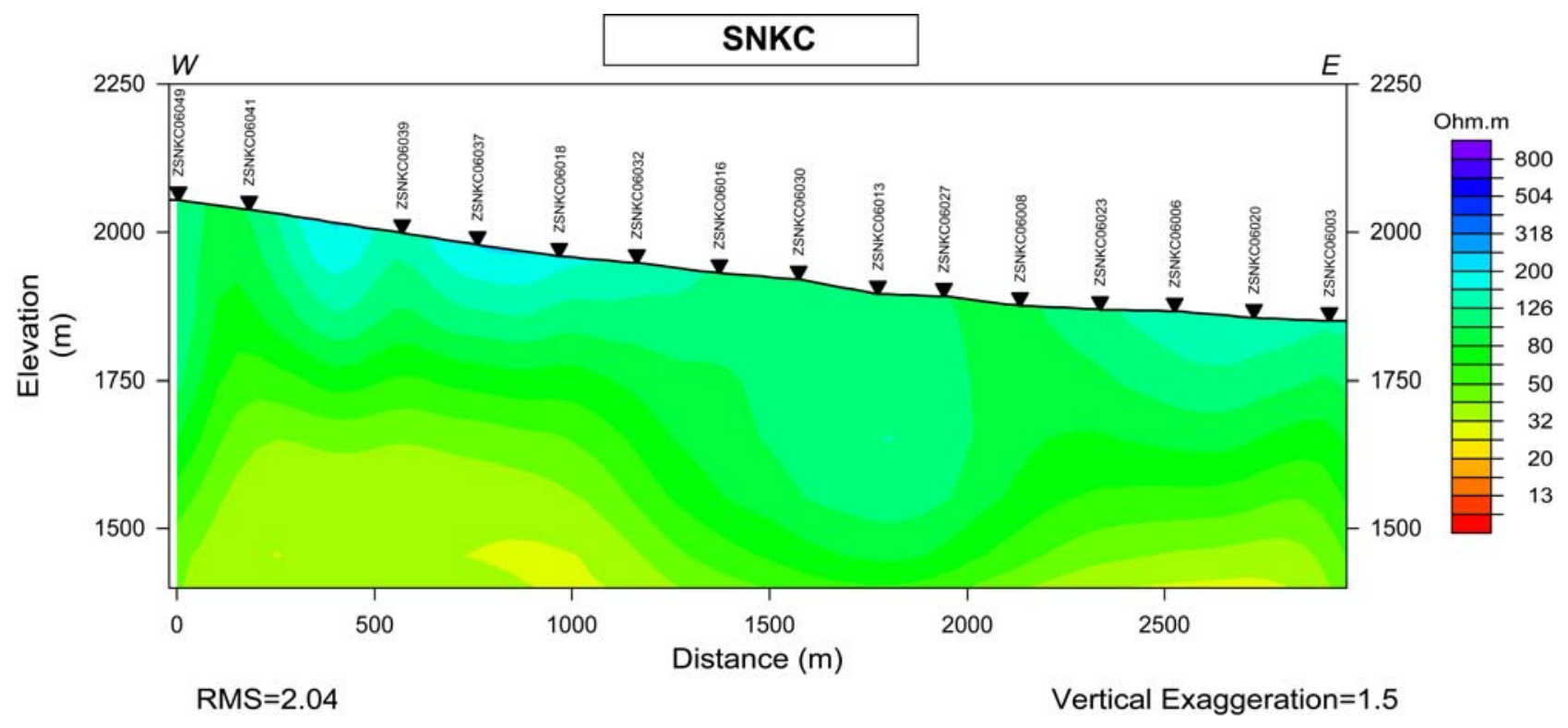

Figure 22. 2-D inverse model computed from the TM mode data along profile SNKC in Snake Valley. 

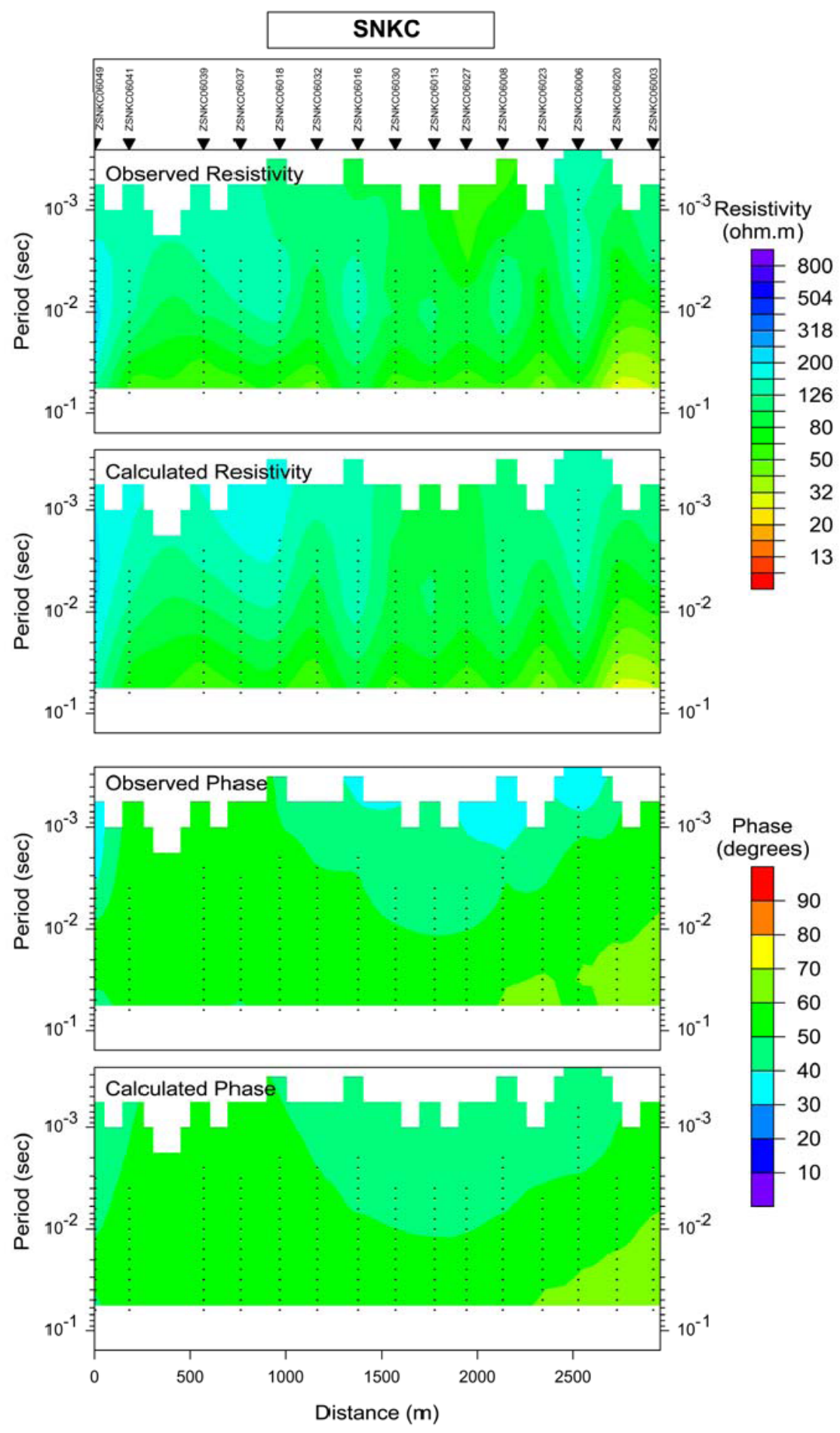

Figure 23. Pseudosections of observed data and model response for the apparent resistivity and phase along profile SNKC. Black dots show data points. 


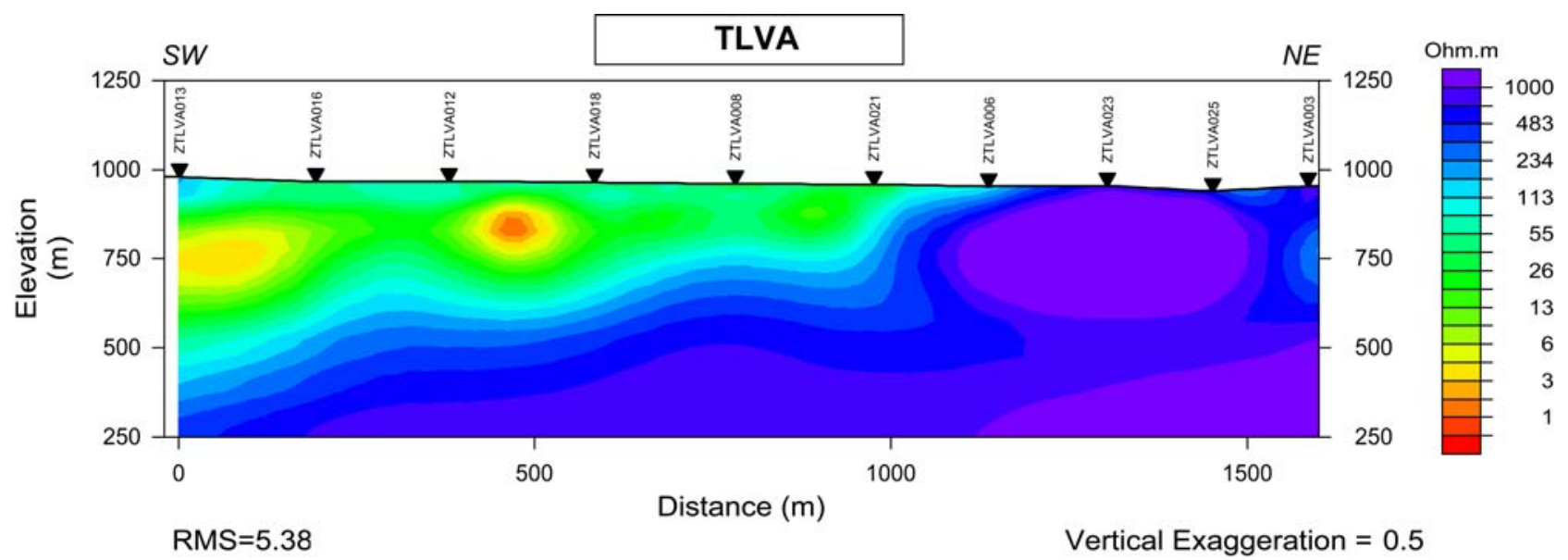

Figure 24. 2-D inverse model computed from the TE+TM mode data along profile TLVA in Three Lakes Valley. Note that resistivity scale is different from that used in Spring and Snake Valley models.

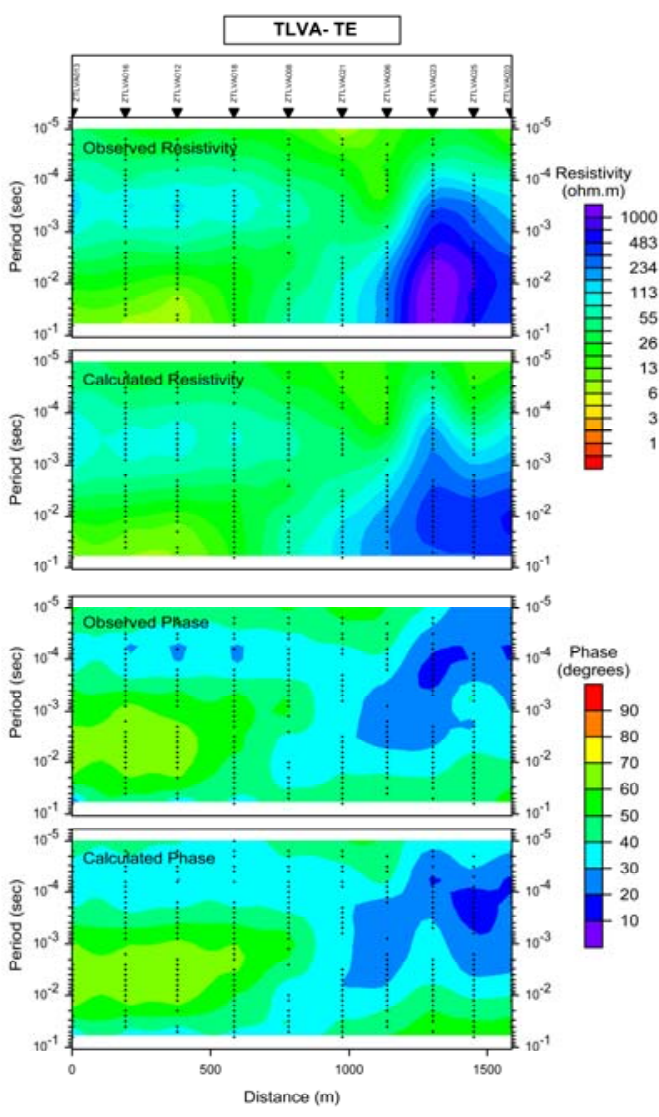

(a)
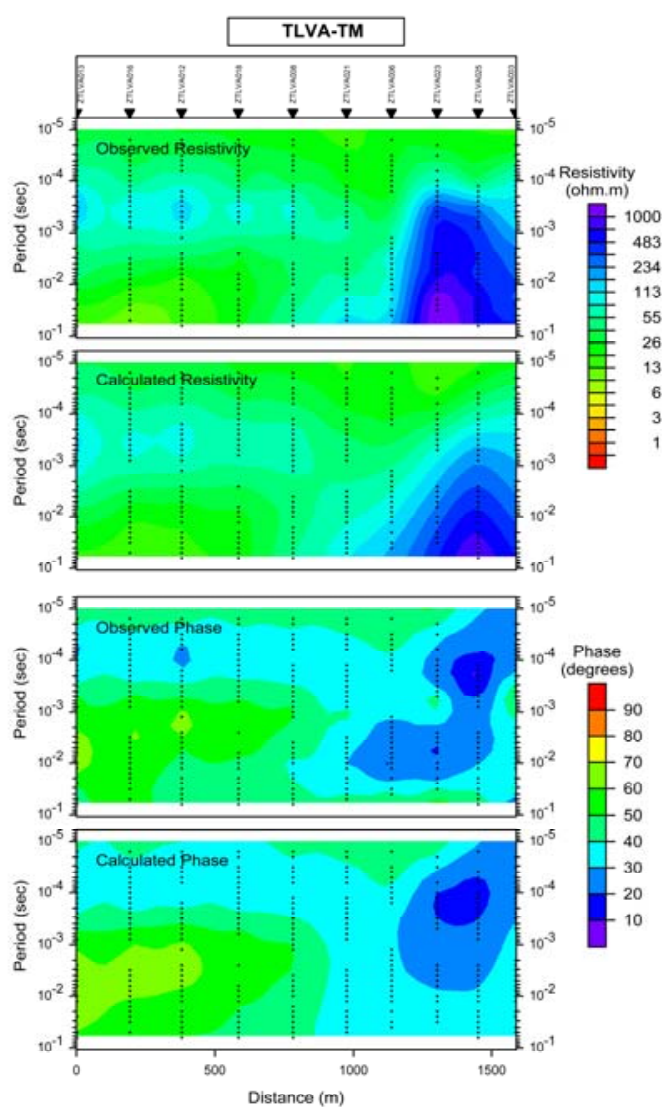

(b)

Figure 25. Pseudosections of observed data and model response for the apparent resistivity and phase along profile TLVA for both the TE (a) and TM (b) modes. Black dots show data points. 


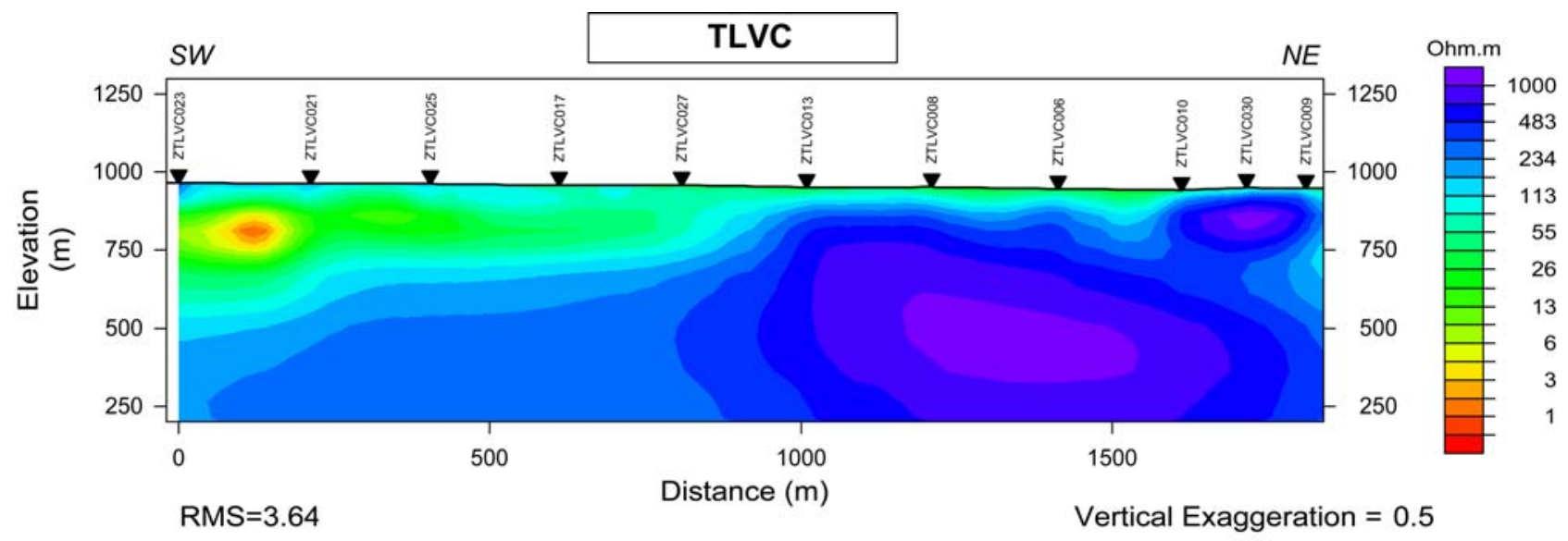

Figure 26. 2-D inverse model computed from the TE+TM mode data along profile TLVC in Three Lakes Valley.

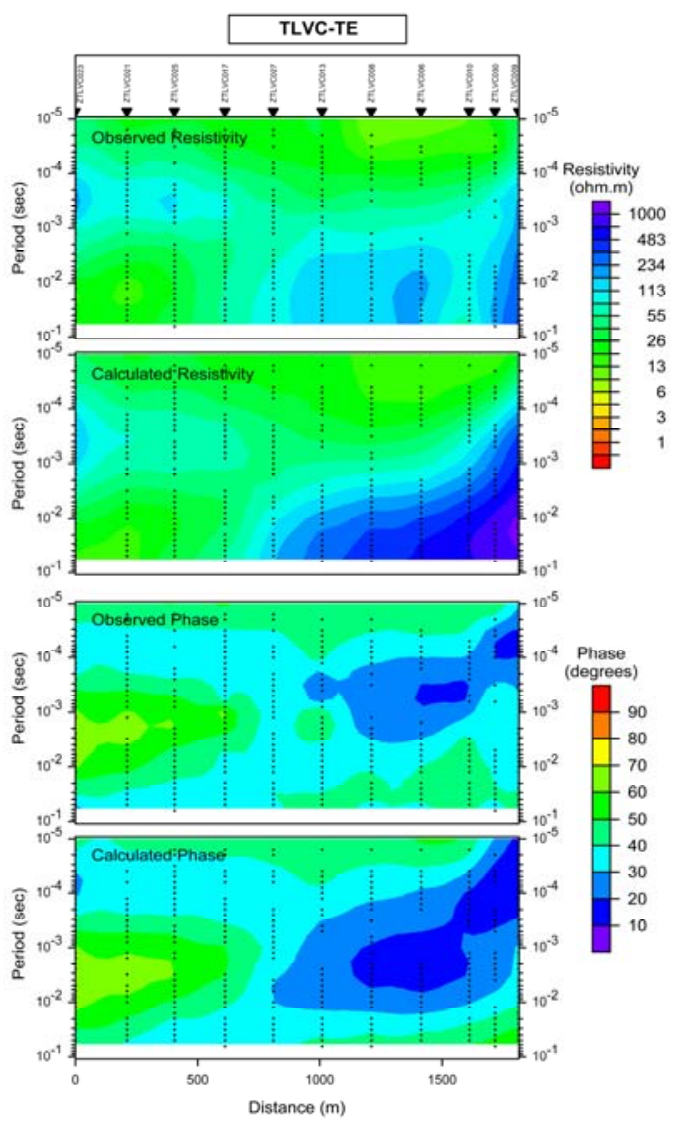

(a)

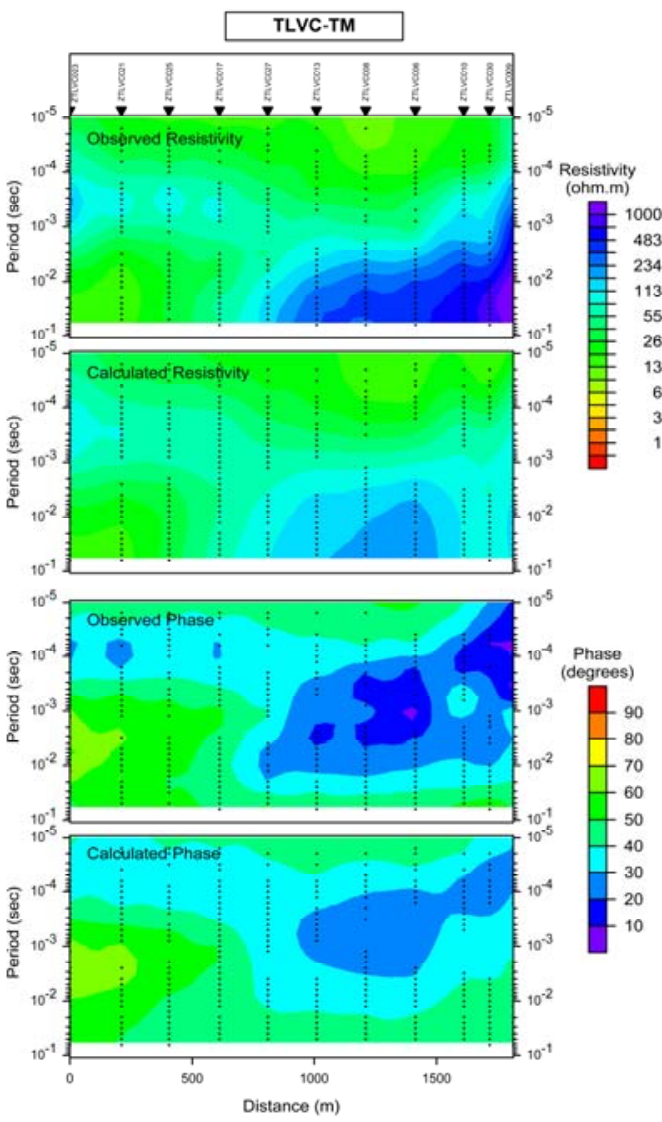

(b)

Figure 27. Pseudosections of observed data and model response for the apparent resistivity and phase along profile TLVC for both the TE (a) and TM (b) modes. Black dots show data points. 
Table 1. Description of AMT profiles.

[Profile azimuth in degrees relative to magnetic North]

\begin{tabular}{|c|c|c|c|c|c|}
\hline $\begin{array}{l}\text { Profile } \\
\text { Name }\end{array}$ & $\begin{array}{c}\text { Length } \\
(\mathbf{k m})\end{array}$ & $\begin{array}{c}\text { Profile } \\
\text { Azimuth }\end{array}$ & $\begin{array}{c}\text { Station } \\
\text { Spacing }(\mathbf{m})\end{array}$ & $\begin{array}{l}\text { Number of } \\
\text { Stations }\end{array}$ & Comments \\
\hline SVNF & 3.25 & $100^{\circ}$ & $200-400$ & 12 & $\begin{array}{c}\text { Western, central Spring V., } \\
\text { near Cleve Creek }\end{array}$ \\
\hline SVNH & 2.4 & $100^{\circ}$ & 200 & 14 & $\begin{array}{l}\text { Western, central Spring V., } \\
\text { near Cooper Creek }\end{array}$ \\
\hline SVNI & 1.66 & $104^{\circ}$ & 200 & 10 & Western, central Spring V. \\
\hline SVNG & 2.6 & $87^{0}$ & 200 & 14 & $\begin{array}{l}\text { Southwestern Spring V., from } \\
\text { margin of Fortification Range to road } \\
\text { to Atlanta }\end{array}$ \\
\hline SVNM & 1.2 & $105^{\circ}$ & 200 & 7 & $\begin{array}{c}\text { Southeastern Spring V., } \\
\text { near Silver Bell Mine }\end{array}$ \\
\hline SVNK & 2.0 & $105^{\circ}$ & 200 & 11 & $\begin{array}{c}\text { Southeastern Spring V., } \\
\text { near Murphy Wash }\end{array}$ \\
\hline SVNL & 2.0 & $90^{\circ}$ & 200 & 12 & Southeastern Spring V. \\
\hline SVNJ & 2.6 & $18^{\circ}$ & 200 & 14 & $\begin{array}{c}\text { Southeastern Spring V., pass between } \\
\text { the Snake Range and the Limestone } \\
\text { Hills near The Troughs }\end{array}$ \\
\hline SNKA & 4.6 & $57^{\circ}$ & $200-400$ & 22 & Southwestern Snake V. \\
\hline SNKB & 3.6 & $90^{\circ}$ & $200-400$ & 19 & $\begin{array}{c}\text { Southwestern Snake V., } \\
\text { road along Lexington Creek }\end{array}$ \\
\hline SNKC & 3.0 & $77^{\circ}$ & $200-400$ & 15 & Southwestern Snake V. \\
\hline TLVA & 1.6 & $235^{\circ}$ & $100-200$ & 10 & Southwestern Three Lakes V. \\
\hline TLVC & 1.8 & $215^{\circ}$ & $100-200$ & 11 & Southwestern Three Lakes V. \\
\hline
\end{tabular}


Table 2. Sounding numbers, locations, elevations and azimuths of stations along AMT profiles.

[Numbers in station name refer to distance along profile in meters (Note that not all of the profiles begin at $0000 \mathrm{~m}$ ). Sounding is preferred sounding used in 2-D model. Horizontal locations are referenced to NAD 27, and Universal Transverse Mercator (zone 11N) units are in meters. Horizontal locations are accurate to approximately $3 \mathrm{~m}$ (10 ft)

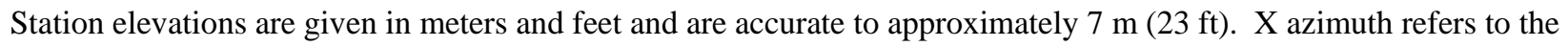
orientation relative to magnetic North of the positive $\mathrm{x}$-component. ]

\begin{tabular}{|c|c|c|c|c|c|c|}
\hline Station & Sounding & Easting (m) & Northing (m) & $\begin{array}{c}\text { Elevation } \\
\text { (ft) }\end{array}$ & $\begin{array}{l}\text { Elevation } \\
(\mathrm{m})\end{array}$ & $\mathrm{X}$ azimuth \\
\hline \multicolumn{7}{|c|}{ SVNF } \\
\hline SVNF0000 & 003 & 711972 & 4343121 & 6253 & 1906 & 90 \\
\hline SVNF0200 & 025 & 712169 & 4343097 & 6286 & 1916 & 90 \\
\hline SVNF0450 & 005 & 712423 & 4343105 & 6224 & 1897 & 90 \\
\hline SVNF0850 & 006 & 712749 & 4342885 & 6198 & 1889 & 90 \\
\hline SVNF1250 & 011 & 713124 & 4342729 & 6168 & 1880 & 90 \\
\hline SVNF1650 & 013 & 713523 & 4342730 & 6132 & 1869 & 90 \\
\hline SVNF2050 & 014 & 713915 & 4342719 & 6115 & 1864 & 90 \\
\hline SVNF2450 & 015 & 714300 & 4342642 & 6060 & 1847 & 90 \\
\hline SVNF2650 & 024 & 714491 & 4342603 & 6030 & 1838 & 90 \\
\hline SVNF2850 & 018 & 714686 & 4342559 & 6017 & 1834 & 90 \\
\hline SVNF3050 & 023 & 714878 & 4342530 & 5994 & 1827 & 90 \\
\hline SVNF3250 & 020 & 715075 & 4342483 & 5988 & 1825 & 90 \\
\hline \multicolumn{7}{|c|}{ SVNH } \\
\hline SVNH0000 & 001 & 710719 & 4328688 & 6378 & 1944 & 90 \\
\hline SVNH0200 & 005 & 710906 & 4328737 & 6270 & 1911 & 90 \\
\hline SVNH0250 & 039 & 710964 & 4328771 & 6306 & 1922 & 90 \\
\hline SVNH0400 & 010 & 711064 & 4328830 & 6270 & 1911 & 90 \\
\hline SVNH0600 & 037 & 711305 & 4328837 & 6214 & 1894 & 90 \\
\hline SVNH0800 & 013 & 711516 & 4328721 & 6171 & 1881 & 90 \\
\hline SVNH1000 & 034 & 711694 & 4328662 & 6161 & 1878 & 90 \\
\hline SVNH1200 & 018 & 711912 & 4328653 & 6148 & 1874 & 90 \\
\hline SVNH1400 & 030 & 712136 & 4328695 & 6132 & 1869 & 90 \\
\hline SVNH1600 & 021 & 712302 & 4328714 & 6132 & 1869 & 90 \\
\hline SVNH1800 & 028 & 712486 & 4328582 & 6122 & 1866 & 90 \\
\hline SVNH2000 & 022 & 712643 & 4328471 & 6089 & 1856 & 90 \\
\hline SVNH2200 & 027 & 712810 & 4328327 & 6053 & 1845 & 90 \\
\hline SVNH2400 & 025 & 712982 & 4328246 & 6043 & 1842 & 90 \\
\hline \multicolumn{7}{|c|}{ SVNI } \\
\hline SVNI0000 & 041 & 710826 & 4324916 & 6152 & 1875 & 90 \\
\hline SVNI0200 & 050 & 711019 & 4324890 & 6122 & 1866 & 90 \\
\hline SVNI0400 & 052 & 711185 & 4324788 & 6089 & 1856 & 90 \\
\hline
\end{tabular}




\begin{tabular}{|c|c|c|c|c|c|c|}
\hline SVNI0600 & 077 & 711356 & 4324690 & 6073 & 1851 & 90 \\
\hline SVNI0800 & 054 & 711530 & 4324601 & 6083 & 1854 & 90 \\
\hline SVNI1000 & 071 & 711721 & 4324522 & 6047 & 1843 & 90 \\
\hline SVNI1200 & 055 & 711894 & 4324443 & 6056 & 1846 & 90 \\
\hline SVNI1400 & 067 & 712052 & 4324532 & 6040 & 1841 & 90 \\
\hline SVNI1600 & 058 & 712249 & 4324573 & 6001 & 1829 & 90 \\
\hline SVNI1660 & 063 & 712306 & 4324600 & 5988 & 1825 & 90 \\
\hline \multicolumn{7}{|c|}{ SVNG } \\
\hline SVNG0000 & 002 & 724323 & 4274128 & 6368 & 1941 & 90 \\
\hline SVNG0200 & 028 & 724511 & 4274134 & 6348 & 1935 & 90 \\
\hline SVNG0400 & 004 & 724742 & 4274146 & 6309 & 1923 & 90 \\
\hline SVNG0600 & 026 & 724953 & 4274138 & 6270 & 1911 & 90 \\
\hline SVNG0800 & 006 & 725129 & 4274168 & 6237 & 1901 & 90 \\
\hline SVNG1000 & 023 & 725321 & 4274177 & 6243 & 1903 & 90 \\
\hline SVNG1200 & 009 & 725510 & 4274188 & 6194 & 1888 & 90 \\
\hline SVNG1400 & 020 & 725707 & 4274195 & 6178 & 1883 & 90 \\
\hline SVNG1600 & 011 & 725910 & 4274199 & 6152 & 1875 & 90 \\
\hline SVNG1800 & 019 & 726084 & 4274210 & 6129 & 1868 & 90 \\
\hline SVNG2000 & 013 & 726307 & 4274214 & 6161 & 1878 & 90 \\
\hline SVNG2200 & 018 & 726515 & 4274220 & 6083 & 1854 & 90 \\
\hline SVNG2400 & 014 & 726712 & 4274238 & 6086 & 1855 & 90 \\
\hline SVNG2600 & 017 & 726915 & 4274248 & 6047 & 1843 & 90 \\
\hline \multicolumn{7}{|c|}{ SVNM } \\
\hline SVNM0400 & 002 & 728616 & 4297449 & 6060 & 1847 & 80 \\
\hline SVNM0600 & 006 & 728800 & 4297366 & 6077 & 1852 & 80 \\
\hline SVNM0800 & 009 & 728982 & 4297287 & 6102 & 1860 & 80 \\
\hline SVNM1000 & 013 & 729173 & 4297215 & 6139 & 1871 & 80 \\
\hline SVNM1200 & 015 & 729368 & 4297173 & 6188 & 1886 & 80 \\
\hline SVNM1400 & 018 & 729564 & 4297131 & 6240 & 1902 & 80 \\
\hline SVNM1600 & 022 & 729801 & 4297200 & 6335 & 1931 & 80 \\
\hline \multicolumn{7}{|c|}{ SVNK } \\
\hline SVNK0200 & 057 & 729177 & 4290814 & 6109 & 1862 & 60 \\
\hline SVNK0400 & 001 & 729371 & 4290736 & 6152 & 1875 & 60 \\
\hline SVNK0600 & 036 & 729573 & 4290690 & 6180 & 1884 & 60 \\
\hline SVNK0800 & 007 & 729764 & 4290639 & 6215 & 1894 & 60 \\
\hline SVNK1000 & 040 & 729955 & 4290578 & 6240 & 1902 & 60 \\
\hline SVNK1200 & 012 & 730155 & 4290529 & 6267 & 1910 & 60 \\
\hline SVNK1400 & 046 & 730340 & 4290463 & 6299 & 1920 & 60 \\
\hline SVNK1600 & 018 & 730532 & 4290402 & 6315 & 1925 & 60 \\
\hline SVNK1800 & 052 & 730724 & 4290351 & 6385 & 1946 & 60 \\
\hline SVNK2000 & 022 & 730925 & 4290316 & 6398 & 1950 & 60 \\
\hline SVNK2200 & 029 & 731129 & 4290296 & 6424 & 1958 & 60 \\
\hline \multicolumn{7}{|c|}{ SVNL } \\
\hline SVNL0400 & 023 & 731793 & 4281872 & 6100 & 1859 & 80 \\
\hline
\end{tabular}




\begin{tabular}{|c|c|c|c|c|c|c|}
\hline SVNL0600 & 026 & 731992 & 4281883 & 6087 & 1855 & 80 \\
\hline SVNL0800 & 028 & 732194 & 4281895 & 6141 & 1872 & 80 \\
\hline SVNL1000 & 030 & 732391 & 4281896 & 6148 & 1874 & 80 \\
\hline SVNL1200 & 033 & 732592 & 4281903 & 6141 & 1872 & 80 \\
\hline SVNL1400 & 015 & 732790 & 4281903 & 6133 & 1869 & 80 \\
\hline SVNL1600 & 017 & 732992 & 4281913 & 6158 & 1877 & 80 \\
\hline SVNL1800 & 039 & 733192 & 4281917 & 6167 & 1880 & 80 \\
\hline SVNL2000 & 002 & 733392 & 4281927 & 6184 & 1885 & 80 \\
\hline SVNL2050 & 036 & 733441 & 4281922 & 6207 & 1892 & 80 \\
\hline SVNL2200 & 008 & 733594 & 4281938 & 6192 & 1887 & 80 \\
\hline SVNL2400 & 012 & 733791 & 4281939 & 6184 & 1885 & 80 \\
\hline \multicolumn{7}{|c|}{ SVNJ } \\
\hline SVNJ0200 & 037 & 737155 & 4277622 & 6029 & 1838 & 60 \\
\hline SVNJ0400 & 035 & 737229 & 4277808 & 6017 & 1834 & 60 \\
\hline SVNJ0600 & 017 & 737299 & 4277987 & 6006 & 1831 & 60 \\
\hline SVNJ0800 & 002 & 737368 & 4278180 & 5977 & 1822 & 60 \\
\hline SVNJ1000 & 020 & 737451 & 4278371 & 5987 & 1825 & 60 \\
\hline SVNJ1200 & 005 & 737521 & 4278554 & 5994 & 1827 & 60 \\
\hline SVNJ1400 & 023 & 737596 & 4278739 & 6012 & 1832 & 60 \\
\hline SVNJ1600 & 006 & 737664 & 4278924 & 6021 & 1835 & 60 \\
\hline SVNJ1800 & 025 & 737677 & 4279142 & 6065 & 1849 & 60 \\
\hline SVNJ2000 & 008 & 737799 & 4279272 & 6057 & 1846 & 60 \\
\hline SVNJ2200 & 028 & 737901 & 4279480 & 6081 & 1853 & 60 \\
\hline SVNJ2400 & 011 & 737976 & 4279666 & 6120 & 1865 & 60 \\
\hline SVNJ2600 & 033 & 737946 & 4279889 & 6122 & 1866 & 60 \\
\hline SVNJ2800 & 015 & 737890 & 4280124 & 6164 & 1879 & 60 \\
\hline \multicolumn{7}{|c|}{ SNKA } \\
\hline SNKA0000 & 001 & 751105 & 4308783 & 6259 & 1908 & 90 \\
\hline SNKA0200 & 050 & 751246 & 4308897 & 6255 & 1907 & 135 \\
\hline SNKA0440 & 005 & 751494 & 4308996 & 6221 & 1896 & 90 \\
\hline SNKA0600 & 045 & 751648 & 4309057 & 6184 & 1885 & 135 \\
\hline SNKA0800 & 007 & 751855 & 4309077 & 6132 & 1869 & 135 \\
\hline SNKA1000 & 044 & 752066 & 4309114 & 6090 & 1856 & 135 \\
\hline SNKA1200 & 009 & 752260 & 4309122 & 6072 & 1851 & 135 \\
\hline SNKA1400 & 042 & 752448 & 4309167 & 6028 & 1837 & 135 \\
\hline SNKA1600 & 011 & 752652 & 4309259 & 5973 & 1821 & 135 \\
\hline SNKA1800 & 040 & 752828 & 4309377 & 5969 & 1819 & 135 \\
\hline SNKA2000 & 013 & 752999 & 4309501 & 5912 & 1802 & 135 \\
\hline SNKA2200 & 016 & 753142 & 4309624 & 5891 & 1796 & 135 \\
\hline SNKA2630 & 017 & 753401 & 4309983 & 5821 & 1774 & 135 \\
\hline SNKA2800 & 038 & 753553 & 4310061 & 5793 & 1766 & 135 \\
\hline SNKA3000 & 020 & 753709 & 4310207 & 5815 & 1772 & 135 \\
\hline SNKA3200 & 035 & 753857 & 4310320 & 5711 & 1741 & 135 \\
\hline SNKA3600 & 033 & 754180 & 4310545 & 5676 & 1730 & 135 \\
\hline SNKA3800 & 025 & 754405 & 4310689 & 5661 & 1725 & 135 \\
\hline SNKA4000 & 032 & 754505 & 4310779 & 5604 & 1708 & 135 \\
\hline
\end{tabular}




\begin{tabular}{|c|c|c|c|c|c|c|}
\hline SNKA4200 & 027 & 754680 & 4310925 & 5603 & 1708 & 90 \\
\hline SNKA4400 & 030 & 754828 & 4311041 & 5566 & 1697 & 135 \\
\hline SNKA4600 & 028 & 754997 & 4311154 & 5509 & 1679 & 135 \\
\hline \multicolumn{7}{|c|}{ SNKB } \\
\hline SNKB0000 & 024 & 749922 & 4304136 & 6554 & 2021 & 90 \\
\hline SNKB0200 & 029 & 750129 & 4304142 & 6481 & 1999 & 90 \\
\hline SNKB0400 & 027 & 750330 & 4304111 & 6446 & 1965 & 90 \\
\hline SNKB0600 & 021 & 750525 & 4304091 & 6370 & 1965 & 135 \\
\hline SNKB0800 & 034 & 750697 & 4303999 & 6346 & 1957 & 90 \\
\hline SNKB1000 & 018 & 750932 & 4303941 & 6322 & 1950 & 135 \\
\hline SNKB1200 & 037 & 751141 & 4303898 & 6266 & 1932 & 135 \\
\hline SNKB1400 & 015 & 751334 & 4303990 & 6225 & 1920 & 135 \\
\hline SNKB1600 & 040 & 751529 & 4303985 & 6213 & 1916 & 135 \\
\hline SNKB1800 & 013 & 751748 & 4303956 & 6171 & 1903 & 135 \\
\hline SNKB2000 & 043 & 751919 & 4303966 & 6139 & 1893 & 135 \\
\hline SNKB2200 & 010 & 752132 & 4304009 & 6117 & 1886 & 135 \\
\hline SNKB2400 & 048 & 752327 & 4304073 & 6084 & 1876 & 135 \\
\hline SNKB2600 & 009 & 752523 & 4304115 & 6057 & 1868 & 135 \\
\hline SNKB2800 & 053 & 752726 & 4304106 & 6027 & 1859 & 135 \\
\hline SNKB3000 & 006 & 752942 & 4304116 & 6005 & 1852 & 135 \\
\hline SNKB3200 & 004 & 753125 & 4304171 & 6054 & 1867 & 135 \\
\hline SNKB3400 & 002 & 753300 & 4304168 & 5927 & 1828 & 135 \\
\hline SNKB3800 & 055 & 753690 & 4304207 & 5925 & 1806 & 135 \\
\hline \multicolumn{7}{|c|}{ SNKC } \\
\hline SNKC0600 & 049 & 747492 & 4298975 & 6740 & 2054 & 20 \\
\hline SNKC0800 & 041 & 747652 & 4299078 & 6687 & 2038 & 45 \\
\hline SNKC1200 & 039 & 748007 & 4299258 & 6556 & 1998 & 35 \\
\hline SNKC1400 & 037 & 748187 & 4299325 & 6491 & 1978 & 45 \\
\hline SNKC1600 & 018 & 748383 & 4299395 & 6427 & 1959 & 55 \\
\hline SNKC1800 & 032 & 748578 & 4299422 & 6390 & 1948 & 90 \\
\hline SNKC2000 & 016 & 748774 & 4299501 & 6334 & 1931 & 90 \\
\hline SNKC2200 & 030 & 748976 & 4299516 & 6299 & 1920 & 90 \\
\hline SNKC2400 & 013 & 749180 & 4299528 & 6219 & 1896 & 90 \\
\hline SNKC2600 & 027 & 749373 & 4299443 & 6205 & 1891 & 90 \\
\hline SNKC2800 & 008 & 749587 & 4299372 & 6154 & 1876 & 90 \\
\hline SNKC3000 & 023 & 749787 & 4299409 & 6133 & 1869 & 90 \\
\hline SNKC3200 & 006 & 749966 & 4299474 & 6123 & 1866 & 90 \\
\hline SNKC3400 & 020 & 750161 & 4299517 & 6087 & 1855 & 90 \\
\hline SNKC3600 & 003 & 750363 & 4299499 & 6069 & 1850 & 90 \\
\hline \multicolumn{7}{|c|}{ TLVA } \\
\hline TLVA0000 & 003 & 624772 & 4048581 & 3129 & 954 & 180 \\
\hline TLVA0150 & 025 & 624691 & 4048474 & 3083 & 940 & 225 \\
\hline TLVA0300 & 023 & 624608 & 4048352 & 3133 & 955 & 180 \\
\hline TLVA0450 & 006 & 624543 & 4048195 & 3126 & 953 & 180 \\
\hline TLVA0600 & 021 & 624441 & 4048069 & 3146 & 959 & 225 \\
\hline
\end{tabular}




\begin{tabular}{|l|l|l|l|l|l|l|}
\hline TLVA0800 & 008 & 624339 & 4047904 & 3149 & 960 & 225 \\
\hline TLVA1000 & 018 & 624248 & 4047726 & 3162 & 964 & 225 \\
\hline TLVA1200 & 012 & 624104 & 4047578 & 3175 & 968 & 225 \\
\hline TLVA1400 & 016 & 623968 & 4047445 & 3172 & 967 & 225 \\
\hline TLVA1600 & 013 & 623868 & 4047282 & 3211 & 979 & 225 \\
\hline \multicolumn{7}{|l|}{} \\
\hline \multicolumn{7}{|l|}{ TLVC } \\
\hline TLVC0000-2 & 009 & 625600 & 4048481 & 3106 & 947 & 225 \\
\hline TLVC0100 & 030 & 625525 & 4048420 & 3116 & 950 & 225 \\
\hline TLVC0200 & 010 & 625440 & 4048360 & 3090 & 942 & 225 \\
\hline TLVC0400 & 006 & 625284 & 4048236 & 3103 & 946 & 225 \\
\hline TLVC0600 & 008 & 625111 & 4048130 & 3123 & 952 & 225 \\
\hline TLVC0800 & 013 & 624937 & 4048028 & 3120 & 951 & 225 \\
\hline TLVC1000 & 027 & 624764 & 4047926 & 3143 & 958 & 225 \\
\hline TLVC1200 & 017 & 624588 & 4047835 & 3139 & 957 & 225 \\
\hline TLVC1400 & 025 & 624413 & 4047723 & 3156 & 962 & 225 \\
\hline TLVC1600 & 021 & 624280 & 4047575 & 3159 & 963 & 225 \\
\hline TLVC1800 & 023 & 624088 & 4047483 & 3166 & 965 & 225 \\
\hline
\end{tabular}

\section{Appendix}

\section{A. Sounding curves.}

The “Audiomagnetotelluric Data” section in this report contains an explanation for three separate plots for each station:

1. Apparent Resistivity curves with x-directed along profile such that the nominal TM mode is ExHy (red diamond) and TE is EyHx (blue square).

2. Impedance Phase curves with x-directed along profile such that the nominal TM mode is ExHy (red diamond) and TE is EyHx (blue square).

3. Multiple E-Predicted Coherencies, defined as (ExHy * Conj(ExHy)) / (Hy * Conj(Hy) * Ex * Conj(Ex)) (red diamond) and (EyHx * Conj(EyHx)) / (Hx * Conj(Hx) * Ey * Conj(Ey)) (blue square)

Sounding curves are named by profile name and distance along the profile (m). 